\title{
The Object and Purpose of a Treaty's Object and Purpose
}

\author{
DINOKRITSIOTIS
}

\section{Introduction}

On seven occasions, the 1969 Vienna Convention on the Law of Treaties (VCLT) invokes the concept of a treaty's object and purpose: in perhaps its most celebrated iteration, Article 18 provides that '[a] State is obliged to refrain from acts which would defeat the object and purpose of a treaty when: (a) it has signed the treaty or has exchanged instruments constituting the treaty subject to ratification, acceptance or approval, until it shall have made its intention clear not to become a party to the treaty; or (b) it has expressed its consent to be bound by the treaty, pending the entry into force of the treaty and provided that such entry into force is not unduly delayed'. ${ }^{1}$ The concept also arises twice in the context of reservations to treaties; ${ }^{2}$ twice, too, with regard to the interpretation of treaties; ${ }^{3}$ and, then, once apiece for the modification ${ }^{4}$ and suspension of multilateral treaties. ${ }^{5}$ On an altogether separate occasion, reference is made to 'the object or purpose' of a treaty: this is done for the purpose of defining the concept of 'material breach' in Article 60 as '(a) [a] repudiation of the treaty not sanctioned by the present Convention; or (b) the violation of a provision essential to the accomplishment of the object or purpose of a treaty. ${ }^{6}$

11155 UNTS 331.

2 Specifically, with regard to their permissibility/opposability: Arts. 19(c) and 20(2) VCLT: ibid.

3 As part of its general rule on interpretation (Art. 31(1) VCLT) as well as its rule on interpretation of treaties that have been authenticated in two or more languages (Art. 33(4) VCLT): ibid.

${ }^{4}$ Art. 41(1) VCLT: ibid. ${ }^{5}$ Art. 58(1) VCLT: ibid.

${ }^{6}$ Art. 60(3) VCLT (emphasis added): ibid. Some appear, though, to gloss over this formulation, writing for example of the 'eight times' that the Vienna Convention puts the concept to use: D. S. Jonas and T. N. Saunders, 'The Object and Purpose of a Treaty: Three Interpretative Methods', Vanderbilt JTL, 43 (2010), 565-609, at 569 and 576. See, also, T. Giegerich, 'Article 60 ' in O. Dörr and K. Schmalenbach (eds.), Vienna Convention on the Law of Treaties: 
The repeated references to a treaty's object and purpose - or to a treaty's object or purpose - are significant, for they either recast or confirm our understanding of the structure or, more appropriately, the anatomy of any given treaty by averting our gaze away from the four corners of its text - from our perennial obsessions with lex scripta - to something that is altogether more mercurial but which is also, if the Vienna Convention is to be believed, no less real than the written word. Indeed, the Vienna Convention is prone to suggest that the concept of a treaty's object and purpose is inherent in every treaty: in view of the span of provisions just mentioned, it matters not whether a treaty is bilateral or multilateral in terms of its design or reach, ${ }^{7}$ and nor do its materiae alter the prospect of each treaty giving rise to an object and purpose. Almost by definition, a treaty possesses a 'spirit'" or 'ethos'" existing independent from its source text, ${ }^{10}$ and with a certain lightness of touch, the Vienna Convention proceeds to sketch in the faintest of

A Commentary (Berlin: Springer, 2012), pp. 1021-1049, at p. 1031 ('[t]he object and purpose standard laid down in [Art. 60(3) VCLT]') and M. M. Gomaa, Suspension or Termination of Treaties on Grounds of Material Breach (The Hague: Kluwer Law International, 1996), p. 29 (' $[t]$ he object and/or purpose of a treaty'). See, further, Report of the Study Group of the International Law Commission, Fragmentation of International Law: Difficulties Arising from the Divergence and Expansion of International Law (Finalized by M. Koskenniemi), A/CN/4/L/682 (13 Apr. 2006), p. 159 (paragraph 309); M. E. Villiger, Commentary on the 1969 Vienna Convention on the Law of Treaties (Leiden: Martinus Nijhoff, 2009), pp. 730-751; M. Fitzmaurice, 'Material Breach of Treaty: Some Legal Issues', Austrian Rev. Int'l \& European L., 3 (2001), 3-44, at 5; J. Klabbers, 'Some Problems Regarding the Object and Purpose of Treaties', Finnish YbIL, 8 (1997), 138-160, at 142; D. Azaria, Treaties on Transit of Energy Via Pipelines and Countermeasures (Oxford: Oxford University Press, 2015), p. 140, and V. CrnicGrotic, 'Object and Purpose of Treaties in the Vienna Convention on the Law of Treaties', Asian YbIL, 7 (1997), 141-174, at 173.

${ }^{7}$ I.e. had it been confined to marking out the standard for permissible reservations: cf. Arts. 18 and 60 with 19(c) and 20(2) VCLT: supra n. 1.

8 M. A. Rogoff, 'The International Legal Obligations of Signatories to an Unratified Treaty', Maine L. Rev., 32 (1980), 263-299, at 269 and 299 - though consider R. K. Gardiner, Treaty Interpretation (Oxford: Oxford University Press, 2nd ed., 2015), p. 214 that '[c]aution, however, is advisable on this as the "spirit" may suggest a nebulous formulation of what animates the treaty. "Object and purpose" is a more specific point of reference'.

9 See, further, A. Pronto and M. Wood, The International Law Commission 1999-2009 (Vol. IV: Treaties, Final Draft Articles, and Other Materials) (Oxford: Oxford University Press, 2010), p. 742 (on the 'ethos' of a treaty) and Fragmentation Report, supra n. 6, at p. 141 (paragraph 277) (regarding treaties that 'share a similar object and purpose or carry a parallel "ethos").

${ }^{10}$ Even though it has been said that it is 'intrinsic' to that text: Case A 28 Federal Reserve Bank of New York v. Bank Markazi (2000) 36 Iran-US Claims Tribunals Reports 5 (paragraph 58). Of course, it is always possible that the object and purpose of the treaty may be specified within its operative provisions, as is done with the 'objectives' of the 1992 Convention on Biological Diversity: 1760 UNTS 79 (Art. 1). 
outlines the elements of this anatomy - of a treaty's preamble, its provisions, its schedules and annexes but also its 'object and purpose'. ${ }^{11}$

It cannot be said, however, that the concept of a treaty's 'object and purpose' is an invention of the Vienna Convention, for we find that the concept had already been addressed through a range of formulations including 'l'objet et la portée' ('the aim and the scope') of a treaty, ${ }^{12}$ 'le but et l'objet' ('the aim and the object') of a treaty, ${ }^{13}$ 'l'objet et le but' ('the aim and the object') of a treaty ${ }^{14}$ and 'le sens et l'espirit des traités' ('meaning and spirit of the treaties'), ${ }^{15}$ while the Harvard Research in International Law concluded in its 1935 Draft Convention on the Law of Treaties that ' $t$ ] wo or more of the States parties to a treaty to which other States are parties may make a later treaty which will supersede the earlier treaty in their relations inter se, only if ... the latter treaty is not so inconsistent with the general purpose of the earlier treaty as to be likely to frustrate that purpose.'. ${ }^{16}$ Additionally, the Draft Convention referred to the general purpose which [a treaty] is intended to serve' for the exercise of its interpretation, ${ }^{17}$ and it provided that ' $[\mathrm{a}]$ treaty which expressly provides that the obligations stipulated are to be performed in time of war between two or more of the parties, or which by reason of its nature and purpose was manifestly intended by the parties to be operative in time of war between two or more of then, is not terminated or suspended by the beginning of a war between two or more of the parties. ${ }^{18}$ Part of the commitment of this chapter will be to trace the concretisation of the concept in the specific terms of a treaty's object and purpose in

11 Along similar lines, it is worth recalling at this point Ian Sinclair's observation that '[a] reservation is a declaration which is external to the text of a treaty': see I. Sinclair, The Vienna Convention on the Law of Treaties (Manchester: Manchester University Press, 2nd ed., 1984), p. 51. See, also, p. 23 of that work.

12 Competence of the ILO to Regulate, Incidentally, the Personal Work of the Employer, 1926 PCIJ, Series B, No. 13, p. 18.

${ }^{13}$ Interpretation of the Convention Between Greece and Bulgaria Respecting Reciprocal Emigration, Signed at Neuilly-sur-Seine on November 27th, 1919 (Question of the 'Communities'), 1930 PCIJ, Series B, No. 17, p. 21.

14 Interpretation of the Convention of 1919 Concerning Employment of Women During the Night, 1932 PCIJ, Series A/B, No. 50.

15 Minority Schools on Albania, 1935 PCIJ, Series A/B, No. 64, p. 15. All of these examples, supra n. 12, n. 13 and n. 14, are helpfully recounted by I. Buffard and K. Zemanek, 'The "Object and Purpose" of a Treaty: An Enigma?', Austrian Rev. Int'l \& European L., 3 (1998), 311-343, at 315.

16 AJIL Supp., 29 (1935), 653-1226, at 661 (Art. 22(b)). See, further, M. Sørenson, 'The Modification of Collective Treaties without the Consent of All the Contracting Parties', Nordisk Tidsskrift for International Ret, 9 (1938), 150-173.

17 Art. 19(a): ibid., at 661. Also Art. 19(b): ibid.

18 Art. 35(a): ibid., at 664. Also Art. 35(b): ibid., at 664-665. 
the decades preceding the Vienna Convention on the Law of Treaties so that, by the time of the Vienna Convention itself, there was a much more concerted effort to roll out the significance of this concept for the law of treaties more generally - making it work, as the opening inventory to this chapter indicates, across a wide range of different contexts. ${ }^{19}$ Still, with all of these stars now appearing in the constellation, the concept does remain 'a surprisingly elusive one', ${ }^{20}$ quite possibly because in some quarters it is still unclear whether 'object' and 'purpose' are to be treated as separate and distinct propositions. ${ }^{21}$ Others have maintained, however, that what is at stake is a term of art that frames a singular proposition denoting a sure set of pathologies or phenomena within treaty action. ${ }^{22}$

19 For example, as against Art. 18 VCLT (supra n. 1), Art. 9 of the 1935 Draft Convention provided that ' $[\mathrm{u}]$ nless otherwise provided in the treaty itself, a State on behalf of which a treaty has been signed is under no duty to perform the obligations stipulated, prior to the coming into force of the treaty with respect to that State; under some circumstances, however, good faith may require that pending the coming into force of the treaty the State shall, for a reasonable time after signature, refrain from taking action which would render performance by any party of the obligations stipulated impossible or more difficult': supra n. 16, at 658. Additionally, although the 1928 Havana Convention on Treaties contained provisions on interpretation (Art. 3), reservations (Arts. 6 and 7) and relations 'governed by rules other than those established in general conventions' (Art. 18), the concept of a treaty's object is nowhere to be found: AJIL Supp., 29 (1935), 1205-1207.

20 M. Bowman, "Normalizing" the International Convention for the Regulation of Whaling', Michigan JIL, 29 (2008), 293-500, at 300. See, also, A. Aust, Modern Treaty Law and Practice (Cambridge: Cambridge University Press, 3rd ed., 2013), p. 209 ('as we have seen in relation to reservations to treaties, [the concept] can be elusive').

21 As indicated most recently by the International Court of Justice when it made reference to a 'solution' that 'would be contrary to both the object and the purpose of the [1948] Pact [of Bogotá]': Case Concerning Border and Transborder Armed Actions: Nicaragua v. Honduras (Jurisdiction and Admissibility) (1988) ICJ Rep. 69, at p. 89 (paragraph 46). This formulation was picked up and used by Judge Oda in his separate opinion: ibid., pp. 109-125, at pp. 112 and 124. See, also, the formulation contained in Art. 60(3) VCLT: supra n. 1. Indeed, Alain Pellet has been briefly tempted 'to decompose the concept of "the object and purpose of the treaty" by examining its object on the one hand, and its purpose, on the other hand': A. Pellet, 'Article 19 (1969)' in O. Corten and P. Klein (eds.), The Vienna Conventions on the Law of Treaties: A Commentary (Vol. I) (Oxford: Oxford University Press, 2011), pp. 405-488, at p. 449.

22 The conclusion of Klabbers, supra n. 6, at 147-148 (that the travaux préparatoires 'clearly indicate that "object and purpose" is to be regarded as a single notion'). See, further, Buffard and Zemanek, supra n. 15, at 318-319 (noting 'a strong indication that [these] are separate and distinct elements which jointly designate a point of reference for interpretation' while observing, at 325, the German, Austrian and English tradition of treating 'object and purpose' as a 'joint notion' versus 'a stream of French doctrine which gives special attention to the distinction between object and purpose [l'objet et le but] of a treaty'). 
To make some headway with these issues, it is proposed that we examine the operating logic of the concept of a treaty's object and purpose at least in terms of its appeal in introducing an 'eminently objective standard' into the law of treaties where ' $[c]$ onformity or non-conformity with the object and purpose [of a treaty] seem to be independent of any State's opinions on the matter. ${ }^{23}$ We shall want to consider how this standard might have developed or deepened over time within the specific contexts brought to the fore by the Vienna Convention, and this approach informs the essential structure of the present chapter. It is hoped not only that each of these contexts spells out the particular implications that a treaty's object and purpose will have from circumstance to circumstance ${ }^{24}$ but that, taken together, they will provide greater illumination on what this 'unique and versatile criterion' entails, ${ }^{25}$ fundamentally enriching our understanding of the anatomy of treaties and the dynamics of treaty relations as they do so.

\section{Reservations and Reservations to the Genocide Convention (1951)}

Although the concept of a treaty's 'object and purpose' had long been known prior to the adoption of the Vienna Convention on the Law of Treaties of May $1969,{ }^{26}$ it was catapulted to prominence when the International Court of

${ }^{23}$ M. Koskenniemi, From Apology to Utopia: The Structure of International Legal Argument (Cambridge University Press, rev. ed., 2005), p. 369. Koskenniemi is keen to emphasize that this standard 'is not wholly objective' (ibid. (emphasis in original)) and that 'the [International] Court [of Justice] never outlined how such test could be undertaken, nor what criteria were relevant in it' (ibid.). See, also, J. K. Gamble Jr. and M. Frankowska, 'The Significance of Signature to the 1982 Montego Bay Convention on the Law of the Sea', Ocean Dev. \& Int'l L., 14 (1984-1985), 121-160, at 125. Note, too, H. Waldock, First Report on the Law of Treaties, Doc. A/CN.4/144 (20 March 1962), pp. 65-66 ('the principle [of object and purpose] is essentially subjective and unsuitable for use as a general test for determining whether a reserving State is or is not entitled to be considered to a multilateral treaty' while admitting that this does 'express a valuable concept to be taken into account both by States formulating a reservation and by States deciding whether or not to consent to a reservation that has been formulated by another State').

${ }^{24}$ C. A. Bradley, 'Treaty Signature' in D. B. Hollis (ed.), The Oxford Guide to Treaties (Oxford: Oxford University Press, 2012), pp. 208-219, at p. 213.

25 Report of the International Law Commission, Fifty-Ninth Session (May-Aug. 2007), U.N. Doc. Supp. No. 10 (A/62/10), p. 68.

${ }^{26}$ See, further, H. W. Malkin, 'Reservations to Multilateral Conventions', BYbIL, 7 (1926), $141-162$, at 142. 
Justice delivered its advisory opinion in Reservations to the Convention on the Prevention and Punishment of the Crime of Genocide in May $1951 .^{27}$ The advisory opinion involved the Court responding to three 'abstract ${ }^{28}$ questions on the matter of reservations to treaties put to it by the General Assembly in November 1950 in the wake of some eighteen reservations that had been made by eight States to the 1948 United Nations Convention on the Prevention and Punishment of the Crime of Genocide. ${ }^{29}$ The challenge facing Trygve Lie, the first Secretary-General of the United Nations, who served as the depositary to the Convention, ${ }^{30}$ was whether States coming to the Convention with reservations could be counted among the number of States deemed necessary to bring the Convention into force. ${ }^{31}$

The Court commenced its analysis by recalling and emphasising the significance that consent has historically had in treaty relations: consent,

27 Reservations to the Convention on the Prevention and Punishment of the Crime of Genocide (Advisory Opinion) (1951) ICJ Rep. 15. Note, though, that in his dissenting opinion, Judge Alejandro Alvarez wrote, ibid., at p. 54, of 'the aims and objects of the Convention' ('les buts et objectifs de la Convention'). See, further, Klabbers, supra n. 6, at 140 (on the 'modern notion').

28 Ibid., at p. 21 - or, as it was put at another point, 'purely abstract' questions (ibid., at p. 21). This was because ' $t \mathrm{t}$ ] hey refer neither to the reservations which have, in fact, been made to the Convention by certain States, nor to the objections which have been made to such reservations by other States' (p. 21). To refresh our memories, the three questions posited by the General Assembly were as follows:

I. Can the reserving State be regarded as being a party to the Convention while still maintaining its reservation if the reservation is objected to by one or more of the parties to the Convention but not by others?

II. If the answer to Question I is in the affirmative, what is the effect of the reservation between the reserving State and:

(a) the parties which object to the reservation?

(b) those which accept it?

III. What would be the legal effect as regards the answer to Question I if an objection to a reservation is made:

(a) by a signatory which has not yet ratified?

(b) by a State entitled to sign or accede but which has not yet done so?

2978 UNTS 277.

${ }^{30}$ Under Art. 11(2) of the Convention: ibid. Parry writes of how the Genocide Convention is 'remarkable for the cumbersome quality of its formal clauses', where notification of reservations is one of 'nine distinct duties': C. Parry, 'Some Recent Developments in the Making of Multi-Partite Treaties', Transactions G. Soc., 36 (1950), 149-189, at 180.

${ }^{31}$ In accordance with Art. 13(2) of the Convention, it would come into force on the nineteenth day following the date of deposit of the twentieth instrument of ratification or accession: ibid. The Convention's entry into force - on 12 Jan. 1951 - was therefore imminent when the General Assembly referred its three questions to the Court on 16 Nov. 1950 (supra n. 28); the Convention contained no provision on reservations. 
the Court said, not only was essential to realising a State's ambition to become part of a particular treaty but also was the mechanism for ensuring the 'integrity' of a treaty. The Court spoke of 'a generally recognised principle that a multilateral convention is the result of an agreement freely concluded upon its clauses ${ }^{32}$ and that, consequently,

none of the contracting parties is entitled to frustrate or impair, by means of unilateral decisions or particular agreements, the purpose and raison d'être of the convention. To this principle was linked the notion of the integrity of the convention as adopted, a notion which in its traditional concept involved the proposition that no reservation was valid unless it was accepted by all the contracting parties without exception, as would have been the case if it has been stated during negotiations. ${ }^{33}$

Against this imperative of treaty integrity, the Court then considered what it called 'a variety of circumstances' that 'would lead to a more flexible application of this principle' in the specific context of the Genocide Convention, ${ }^{34}$ emphasising 'a new need for flexibility in the operation of multilateral conventions' that would facilitate greater participation therein. ${ }^{35}$ Indeed, the Court inferred from the first of the questions put to it by the General Assembly the existence of a 'faculty' to posit reservations to the Genocide Convention, ${ }^{36}$ which was in fact, the Court said, 'contemplated at successive stages of the drafting of the Convention'. ${ }^{37}$ The Court then turned its attention to the consequences of exercising this faculty, especially 'what kind of

32 Supra note 27, at p. 21. See, also, the contribution to this volume of Craven at pp. 103-135 (Chapter 5).

33 Ibid. (which, the Court said, 'is directly inspired by the notion of contract').

${ }^{34} \mathrm{Ibid}$. For further assessment of this theme of integrity, consider C. Redgwell, 'Universality or Integrity? Some Reflections on Reservations to General Multilateral Treaties', BYbIL, 64 (1993), 245-282, at 251. Though see, also, R. Goodman, 'Human Rights Treaties, Invalid Reservations, and State Consent', AJIL, 96 (2002), 531-560, at 535 ('the modern approach should be viewed as harmonizing - rather than choosing between - universality and integrity').

35 Supra n. 27, at p. 22 (as manifested by '[m] ore general resort to reservations, very great allowance made for tacit assent to reservations, the existence of practices which go so far as to admit that the author of reservations which have been rejected by certain contracting parties is nevertheless to be regarded as a party to the convention in relation to those contracting parties that have accepted the reservations': ibid., at pp. 21-22). See, further, D. R. Anderson, 'Reservations to Multilateral Conventions: A Re-examination', ICLQ, 13 (1964), 450-481.

36 Supra n. 27, at p. 22.

37 Ibid. (where 'the absence of an article providing for reservations' should not be taken to mean 'that the contracting States are prohibited from making certain reservations' as this can be explained 'by the desire not to invite a multiplicity of reservations'). 
reservations may be made and what kind of objections may be taken to them'. ${ }^{38}$ For the Court, ' $\mathrm{t}$ ] he solution of these problems must be found in the special characteristics' of the Convention itself - an approach that brought the Court into closer touch with 'the will of the General Assembly and the parties' to the Convention. ${ }^{39}$ And, in the same breath, the Court maintained that the 'objects' - note the plural here ${ }^{40}$ - of such a convention also had to enter the reckoning:

The Convention was manifestly adopted for a purely humanitarian and civilizing purpose. It is indeed difficult to imagine a convention that might have this dual character to a greater degree, since its object on the one hand is to safeguard the very existence of certain human groups and on the other to confirm and endorse the most elementary principles of humanity. In such a convention the contracting States do not have any interests of their own; they merely have, one and all, a common interest, namely, the accomplishment of those high purposes which are the raison d'être of the convention. Consequently, in a convention of this type one cannot speak of individual advantages or disadvantages of States, or of the maintenance of a perfect contractual balance between rights and duties. The high ideals which inspired the Convention provide, by virtue of the common will of the parties, the foundation and measure of all its provisions. ${ }^{41}$

We can observe the equation the Court appears to draw in this passage between 'object' and 'purpose, ${ }^{42}$ before it moved to articulate the mechanism for regulating 'the effects of objections to reservations, ${ }^{43}$

${ }^{38}$ Ibid., at p. 23.

39 Ibid. (as interpreted from: the origins and character of the Convention; the objects pursued by the General Assembly and the contracting parties; the relations which exist between the provisions of the Convention, inter se, and between those provisions and these objects). Note McNair's observation - in 1961 - that 'the practice of making reservations to multipartite treaties is now so common that some development in mechanism is required': A. D. McNair, The Law of Treaties (Oxford: Clarendon Press, 1961), p. 162. See, also, p. 168.

40 Again, note the Court's reference to 'high purposes': supra n. 27, at p. 24.

${ }^{41}$ Ibid., at p. 23. At a later point in its opinion (at p. 24), the Court made reference to 'the authority of the moral and humanitarian principles which are [the] basis [of the Convention]'.

${ }^{42}$ Indeed, also in the plural ('high purposes'): ibid. Similarly, at p. 24 (re: 'the acceptance of reservations which frustrate the purposes which the General Assembly and the contracting parties had in mind' and 'which may be quite compatible with those purposes').

${ }^{43}$ Ibid., at p. 23. As against 'the conception of the absolute integrity of a convention' which, the Court maintained (at p. 24), had not been 'transformed into a rule of international law'. 
and it is in this context that it made its first reference to the concept of that treaty's 'object and purpose':

The object and purpose of the Genocide Convention imply that it was the intention of the General Assembly and of the States which adopted it that as many States as possible should participate. The complete exclusion from the Convention of one or more States would not only restrict the scope of its application, but would detract from the authority of the moral and humanitarian principles which are its basis. It is inconceivable that the contracting parties readily contemplated that an objection to a minor reservation should produce such a result. But even less could the contracting parties have intended to sacrifice the very object of the Convention in favour of a vain desire to secure as many participants as possible. The object and purpose of the Convention thus limit both freedom of making reservations and that of objecting to them. It follows that it is the compatibility of a reservation with the object and purpose of the Convention that must furnish the criterion for the attitude of a State in making the reservation on accession as well as for the appraisal by a State in objecting to the reservation. Such is the rule of conduct which must guide every State in the appraisal which it must take, individually and from its own standpoint, of the admissibility of any reservation. ${ }^{44}$

What is especially interesting from these passages is how the Court develops an assured intimacy between the intentions of the General Assembly and States adopting the Convention and the object and purpose of the treaty: the Contracting States are there not just qua Contracting States to the Convention but also, and perhaps foremost, as designers or authors of the treaty. The Genocide Convention did not, of course, emerge from thin air: 'The high ideals which inspired the Convention provide', the Court reasoned, 'by virtue of the common will of the parties, the foundation and measure of all of its provisions' ${ }^{45}$ Yet, even with 'the foundation and measure of all of its provisions' in place, the Convention was still not able to yield an answer to the question of whether the aforementioned reservations were valid: for this, the Court had to read into the intention of the authors of the Convention as

${ }^{44}$ Ibid., at p. 24. Indeed, in this formulation, the Court would appear to treat 'object' and 'purpose' as distinct propositions and not as interchangeable with one another or integrated into one generic concept or term of art: 'The object and purpose of the Genocide Convention imply' - not implies. Also, further in the same passage, ' $\mathrm{t}] \mathrm{he}$ object and purpose of the Convention thus limit' - not limits. One is led to wonder whether these nuances somehow became lost once the Court named 'the object and purpose' of the Genocide Convention in this way: see, for instance, the remarks of Paul Reuter, YbILC (1964-I), 26 (paragraph 77).

45 Supra n. 41. 
refracted through the object and purpose of the Convention ('that as many States as possible should participate', or so deduced the Court). ${ }^{46}$ It had to peer beyond the text - that is, beyond the provisions of the Convention - to its very object and purpose to see what this would 'imply': 'It is inconceivable', concluded the Court, 'that the contracting parties readily contemplated that an objection to a minor reservation should produce [the] result' of the 'complete exclusion from the Convention of one or more States. ${ }^{47}$

We can appreciate that it is at this juncture that serious disagreement occurred within the Court, for Judges José Gustavo Guerrero, John Erksine Read, Hsu Mo and Sir Arnold McNair entered a joint dissenting opinion claiming that the approach before them would force 'a corresponding classification of the provisions of the Convention into two categories - of minor and major importance' in terms of their relation to the treaty's object and purpose. ${ }^{48}$ Concerned, too, that 'no legal basis' existed for the scheme articulated by the Court, ${ }^{49}$ these dissenting judges interrogated the operationalisation of a rule that 'hinges' on the identification of a treaty's object and purpose: 'What is the "object and purpose" of the Genocide Convention?', they asked pointedly. 'To repress genocide? Of course; but is it more than that? Does it comprise any or all of the enforcement articles of the Convention? That is the heart of the matter. ${ }^{50}$

46 Supra n. 44.

${ }^{47}$ Ibid. And, elsewhere, supra n. 27, at p. 24: 'Any other view would lead either to the acceptance of reservations which frustrate the purposes which the General Assembly and the contracting parties had in mind, or to recognition that the parties to the Convention have the power of excluding from it the author of a reservation, even a minor one, which may be quite compatible with those purposes'. Also: 'having regard to the character of the convention, its purpose and mode of adoption, it can be established that the parties intended to derogate from that rule by admitting the faculty to make reservations thereto': ibid.

${ }^{48}$ Supra n. 27, at p. $42 . \quad{ }^{49}$ Ibid.

50 Ibid., at p. 44. For these dissenting judges, ' $[\mathrm{w}]$ hen a new rule is proposed for the solution of disputes, it should be easy to apply and calculated to produce final and consistent results'. For its part, the International Law Commission was not far behind in its criticism of this mechanism: in its report on reservations to multilateral conventions to the General Assembly in 1951, the ILC concluded:

24. The Commission believes that the criterion of the compatibility of a reservation with the object and purposes of a multilateral convention, applied by the International Court of Justice to the Convention on Genocide, is not suitable for application to multilateral conventions in general. It involves a classification of the provisions of a convention into two categories, those which do and those which do not form part of its 
Several observations now appear to be in order. First, there can be no doubting the centrality that the Court awarded to the concept of a treaty's object and purpose in its analysis: as A. D. McNair has observed, 'the [C] ourt, in effect, substituted for the requirement of the unanimous consent to a reservation the requirement that it must be "compatible with the object and purpose of the [Genocide] Convention"'. ${ }^{51}$ A treaty's 'object and purpose' thus became the Court's 'uniform piece of machinery' for the task before it, ${ }^{52}$ at the heart of which existed the treaty's integrity - or, we might say, its 'essence'. ${ }^{33}$ That much remains clear; it is not disturbed by any incidental details that we might have teased from the advisory opinion of the Court.

Second, in setting down the object and purpose of a treaty as the 'criterion' for distinguishing valid from invalid reservations, it appears that we are none the wiser as to what the object and purpose of the Genocide Convention might in fact be - at least as it stood (or stood to be deciphered) at that point in time. To be sure, this determination might well have been regarded as surplus to requirements given the nature of the questions put to the Court by the General Assembly, ${ }^{54}$ and, in any event, the Court did make mention of the 'object' of the Convention (which 'on the one hand is to safeguard the very existence of certain human groups and on the other to confirm and endorse the most elementary principles of humanity'). ${ }^{55}$ However, is this to be taken as the totality of the Genocide Convention's object and purpose? What if that totality is simply that which is stated in the preamble to the

object and purpose. It seems reasonable to assume that, ordinarily at least,
the parties regard the provisions of a convention as an integral whole, and
that a reservation to any of them may be deemed to impair its object and
purpose. Even if the distinction between provisions which do and those
which do not form part of the object and purpose of a convention be
regarded as one that it is intrinsically possible to draw, the Commission
does not see how the distinction can be made otherwise than subjectively.

YbILC (1951-II), 128. The Commission was of the view, ibid., at 129, that where a convention places 'no limit on the admissibility of reservations', the preferred approach would be for the text to 'establish a procedure in respect of the tendering of reservations and their effect'.

51 McNair, supra n. 39, at p. 166. McNair is of course referring here to p. 27 of the advisory opinion: supra n. 27.

52 As formulated by McNair: supra n. 39, at p. 170.

53 E. T. Swaine, 'Treaty Reservations' in Hollis (ed.), supra n. 24, pp. 277-301, at p. 285.

${ }^{54}$ Supra n. 28.

55 Supra n. 41 (in a context in which it also adverted to 'those high purposes which are the raison d'être of the convention'). 
Convention - that the Contracting Parties are convinced that international co-operation is required' for dealing with the crime of genocide? ? $^{56}$ What, then, is to be made of the 'prevention' and 'punishment' of this crime as per the Convention's title? And what if, hypothetically, part of the object and purpose of the Convention was the codification of international custom? ${ }^{57}$ Was the Court itself even fully conscious of what it understood the 'special characteristics' of the Genocide Convention to be? For the Court does seem to hint at the potential complexity - the multidimensionality, if you will - of a treaty's object and purpose even in one as short as the Genocide Convention, comprising as it does a mere nineteen articles. '[E]ven less', chides the Court in one moment, 'could the contracting parties have intended to sacrifice the very object of the Convention in favour of a vain desire to secure as many participants as possible, ${ }^{58}$ and yet it is that very 'vain desire' that the Court had earlier derived from ' $t$ the object and purpose of the Genocide Convention' ${ }^{59}$ From what the Court says, there is some sense that a treaty's 'object and purpose' awaits to be determined at different levels of engagement, taking on matters of substance ('to safeguard the very existence of certain human groups'), ${ }^{60}$ the intended structure of legal relations (absent 'the maintenance of a perfect contractual balance between rights and duties') ${ }^{61}$ and its projected sphere of operation ('as many States as possible should participate'). ${ }^{62}$

Third, and perhaps most importantly of all, is the envisaged operationalisation of the Court's scheme: in short, just how was it meant to work in practice? Admittedly, once the object and purpose of the Genocide Convention is known, it does seem to follow - as was anticipated by the four dissenting judges - that different provisions of the Convention will relate to it in different ways or, rather, with differing strengths of connection. The Court said as much later in its advisory

56 Supra n. 29. The preamble actually notes that genocide is a crime under international law - one that is 'contrary to the spirit and aims of the United Nations': ibid.

57 See, further, P. Gaeta, 'On What Conditions Can a State Be Held Responsible for Genocide?', EJIL, 18 (2007), 631-648, at 642.

58 Supra n. 44. ${ }^{59}$ Ibid. (i.e. 'that as many States as possible should participate').

60 Supra n. 41.

61 Ibid. This is brought on by the Court's emphasis of the 'character' of the Convention (supra n. 27, at p. 22), including the 'the universal character both of the condemnation of genocide and of the co-operation required "in order to liberate mankind from such an odious scourge"': ibid., at p. 23 (drawing on the formulation from the preamble of the Genocide Convention). See, further, McNair, supra n. 39, at p. 167.

62 Supra n. 44. 
opinion with its claim that '[i]t must clearly be assumed that the contracting States are desirous of preserving intact at least what is essential to the object of the Convention', ${ }^{63}$ and when it spoke of 'the power of excluding from [the Convention] the author of a reservation, even a minor one, which may be quite compatible with those purposes' ${ }^{64}$ So, at least as far as (proposed) reservations are concerned, an apparent principle of essentiality is in operation, ${ }^{65}$ with the Court having in mind that it is the reserving State that must activate the principle in the first instance: it is the compatibility of a reservation with the object and purpose of the Convention that must furnish the criterion for the attitude of a State in making the reservation on accession'. In the second instance, however, it is also the criterion which should inform 'the appraisal by a State in objecting to the reservation': ' 6 ' $\mathrm{s}] \mathrm{uch}$ is the rule of conduct which must guide every State in the appraisal which it must make, individually and from its own standpoint, of the admissibility of any reservation'. ${ }^{67}$

Under this scheme, one can appreciate that 'whether a reservation is contrary to [a] treaty's object and purpose becomes a question lexically prior to whether States can object' thereto, ${ }^{68}$ and this interpretation is very much supported by the Court's conclusion that '[a] State which has made and maintained a reservation which has been objected to by one or more of the parties to the Convention but not by others, can be regarded as being a party to the Convention if the reservation is compatible with the object and purpose of the Convention' ${ }^{69}$ However, the Court's scheme does seem to make some accommodation for any uncertainties that might result from the identification of the "very" ${ }^{70}$ object and purpose of a treaty, especially given the intricacies associated with that task. This is to say nothing of the essentiality of a proposed reservation to a treaty's object and purpose once that has been identified, since the Court seemed minded to involve States other than the reserving State in an exercise of

${ }^{63}$ Supra n. 27, at p. 27 (emphasis added).

${ }^{64} \mathrm{Ibid}$., at p. 24. Again, plural: supra n. 40 (and accompanying text) and n. 42.

65 One that implies a distinction between all obligations in the treaty and the core obligations that are the treaty's raison d'être': L. Lijnzaad, Reservations to UN Human Rights Treaties: Ratify and Ruin? (Dordrecht: Martinus Nijhoff, 1994), p. 83.

${ }^{66}$ Supra n. 27, at p. $24 .{ }^{67}$ Ibid.

68 B. Çalı, 'Specialized Rules of Treaty Interpretation: Human Rights' in Hollis (ed.), supra n. 24 , pp. $525-548$, at p. 535.

69 Supra n. 27, at p. 29 (emphasis added). The Court's answer to Question I of the General Assembly: supra n. 28 (by seven votes to five).

70 The Court's word: supra n. 44. 
interaction and deliberation: in the Court's words, the 'criterion' of 'the compatibility of a reservation with the object and purpose of [a] Convention' must also ('as well as') inform 'the appraisal by a State in objecting to the reservation' if that should come to pass. ${ }^{71}$

$$
* * *
$$

And so the foundations were set for the rules on reservations that arrived with the Vienna Convention in May 1969 - which preserved the 'presumptive right for States to forge reservations', ${ }^{72}$ and embraced the concept of a treaty's object and purpose for regulating the making of reservations more generally ${ }^{73}$ (i.e. beyond the 'special characteristics' of the Genocide Convention that had so defined the Court's reasoning in the Reservations advisory opinion). ${ }^{74}$ According to Article 19 VCLT, this faculty of States to formulate a reservation exists unless:

(a) the reservation is prohibited by the treaty;

(b) the treaty provides that only specified reservations, which do not include the reservation in question, may be made; or

(c) in cases not falling under sub-paragraphs (a) and (b), the reservation is incompatible with the object and purpose of the treaty. ${ }^{75}$

The inclusion of the concept or "notion"76 of a treaty's 'object and purpose' in this manner surely confirms its status as 'the equilibrium point between the necessity of preserving the essential core of the treaty and the willingness to facilitate membership of an as large as possible

${ }^{71}$ Supra n. 44. Also in the dispositif to Question II (by seven votes to five): 'if a party to the Convention objects to a reservation which it considers incompatible with the object and purpose of the Convention, it can in fact consider that the reserving State is not a party to the Convention'. Supra n. 27, at p. 29.

72 Swaine, supra n. 53, at p. 285.

73 Art. 19(c) VCLT: supra n. 1. Zemanek considers this an instance of the Court having 'initiated new custom': see K. Zemanek, 'Re-examining the Genocide Opinion: Are the Object and Purpose of a Convention Suitable Criteria for Determining the Admissibility of Reservations?' in N. Ando, E. McWhinney and R. Wolfrum (eds.), Liber Amicorum Judge Shigeru Oda (Vol. I) (The Hague: Kluwer Law International, 2002), pp. 335-348, at p. 335. See, also, McNair, supra n. 39, at p. 166 (a 'new test of the admissibility of reservations') and p. 167 ('this new criterion').

${ }^{74}$ Supra n. 27, at p. 23. Note Swaine's observation that the Court had not 'directly confront[ed] the question of whether an object-and-purpose test was hard-wired in all treaties (or, at least, in those that permitted reservations with less than unanimous consent)' where 'the Court's analysis seemed sufficiently context-sensitive to resist easy generalization, and it felt little cause to clarify anything beyond the result for the Genocide Convention itself - or, perhaps, for the greater class of human rights conventions to which it belonged': supra n. 53, at p. 283.

${ }^{75}$ Art. 19 VCLT: supra n. $1 . \quad{ }^{76}$ Pellet, supra n. 21, at p. 445. 
number of States to multilateral conventions, ${ }^{77}$ as well as, ultimately, its significance for the law of treaties more generally, ${ }^{78}$ notwithstanding the ritual uncertainties that continue to surround its actual 'content' and meaning. ${ }^{79}$ Still, the strong and possibly symbolic message coming forward from the Vienna Convention is that States (and, in turn, international organizations) $)^{80}$ do not have free reign to formulate any reservation of their choosing. In particular, when a treaty falls silent on prohibiting or authorising specific reservations to it, ${ }^{81}$ that is not to be treated as an invitation for devising imaginative flights of fancy by a prospective treaty partner since the integrity - the normative integrity of a treaty arrangement is there to be upheld as a matter of the law of treaties. ${ }^{82}$ Of course, ironically or not, this is the position the Vienna Convention finds itself in since it contains no provision on reservations made against its own terms, ${ }^{83}$ and the unadulterated technical nature of the Convention must give some pause for thought as to whether it might be 'virtually impossible' to determine its object and purpose. ${ }^{84}$

77 Ibid., at p. 445 (though, at pp. 419-420, noting that there is in fact a 'double equilibrium' for rules relating to reservations: 'between the prerequisites of universality and the integrity of the treaty' and 'between the liberty of the consent of the reserving State and that of the other States parties').

78 Against, it must be said, some strong initial opposition within the International Law Commission 'as a criterion of a reserving State's status as a party to a treaty in combination with the objective criterion of the acceptance or rejection of the reservation by other States': Waldock, First Report on the Law of Treaties, supra n. 23, at p. 66 (original emphasis).

79 Pellet, supra n. 21, at p. 445 (conceding, though, at p. 415, that ' $\mathrm{t}$ ] his ambiguity, which has never been entirely removed ... has undoubtedly allowed for the adoption of the system and is perhaps even the explanation of its relative success').

80 See Art. 19 of the 1986 Vienna Convention on the Law of Treaties between States and International Organizations or between International Organizations: ILM, 25 (1986), 543-592.

81 Authorised reservations are to be read as implicit prohibitions: Pellet, supra n. 21, at pp. 414 and $443-444$.

82 As Pellet remarks: Art. 19(c) VCLT 'guarantees, if not the integral application of its provisions, at least the integrity of its essential content': supra n. 21, at p. 420. See, also, ibid., at pp. 409 and 427. One thinks of Lijnzaad's vivid image in this respect - that '[a] large number of reservations made by a great many States will turn a human rights instrument into a moth-eaten guarantee': supra n. 65 , at p. 3.

${ }^{83}$ Sinclair, supra n. 11, at pp. 63-68. See, also, Aust, supra n. 20, at p. 124.

84 Aust, supra n. 20, at p. 124. See infra n. 193 (and accompanying text). Not all is lost, however: Sinclair, supra n. 11, at pp. 67-68 ('[a] reservation to Article 66 [VCLT] or to the Annex [to the VCLT] might or might not eventually be determined to be incompatible with the object and purpose of the Convention; certainly, any such reservation, to use the words of the International Law Commission, "undermined the basis of the treaty or of a compromise made in the negotiations"'). Note, too, the Syrian Arab Republic's 'political statement' Sinclair does not regard it as 'a reservation in the strict sense' - to Art. 81 VCLT ('[ $t$ ] he present 
Quite possibly, the Vienna Convention is making clear to authors of future treaties that a potential safeguard against untoward reservations will exist even if disagreement precludes a provision on reservations in their respective texts (Article 19(a) and (b) VCLT). ${ }^{85}$ This will occur through the convenient vector of the treaty's 'object and purpose' (Article 19(c) VCLT). That said, it is not apparent from the Vienna Convention what consequences follow if a reserving State does not correctly intuit for itself ${ }^{86}$ that the reservation it has up its sleeve is not compatible with the aforementioned object and purpose. ${ }^{87}$ If that State runs the risk of positing that reservation, will the reservation be void ab initio (as is proclaimed by the 'permissibility' school), or does it become subject to the Vienna Convention rules on objections (as per the 'opposability' school)? ${ }^{88}$ Importantly, treaty practice either side of the Vienna Convention has explicitly embraced the concept of 'object and purpose' as a means of determining the permissibility of reservations, as in Article 20(2) of the 1965 United Nations Convention on the Elimination of All Forms of Racial Discrimination ${ }^{89}$ and Article 28(2)

Convention shall be open for signature by all States Members of the United Nations or of any of the specialized agencies or of the International Atomic Energy Agency or parties to the Statute of the International Court of Justice, and by any other State invited by the General Assembly of the United Nations to become a party to the Convention, as follows: until 30 November 1969, at the Federal Ministry for Foreign Affairs of the Republic of Austria, and subsequently, until 30 April 1970, at United Nations Headquarters, New York') - that the provision is not in conformity with the aims and purposes of the Convention in that it does not allow all States, without distinction or discrimination, to become parties to it'. Sinclair, supra n. 11, at p. 65. This is significant because of its pluralisation of the 'aims and purposes' of the VCLT, but also because of its indication that 'the sovereign equality and independence of all States' as announced in the sixth preambular recital of the VCLT, forms part of that treaty's object and purpose.

${ }^{85}$ As occurred with Spain's proposal to prohibit reservations to Part V of the Vienna Convention ('Invalidity, Termination and Suspension of the Operation of Treaties') which was rejected by sixty-two votes to nine, with thirty-three abstentions after 'strong objections' had been voiced by Brazil, Israel, the Soviet Union, India, the United Kingdom and Nigeria: Sinclair, supra n. 11, at p. 79. See, also, Aust, supra n. 20, at p. 122.

${ }^{86}$ As is wonderfully put by Swaine: supra n. 53, at p. 285.

${ }^{87}$ One of the contenders, we can presume, of the 'conceal[ed]' difficulties of the Vienna Convention régime: Sinclair, supra n. 11, at p. 62.

88 See Arts. 20 and 21 VCLT: supra n. 1.

89660 UNTS 195 ('[a] reservation incompatible with the object and purpose of this Convention shall not be permitted, nor shall a reservation the effect of which would inhibit the operation of any of the bodies established by this Convention be allowed'). Though the object and purpose of the Convention is not specified in the Convention, the formulation presented is instructive because it gives the impression that any inhibition of 'the operation of any of the bodies established by this Convention' does not pertain to the Convention's object and purpose. 
of the 1979 United Nations Convention on the Elimination of All Forms of Discrimination Against Women. ${ }^{90}$ This is interesting because these provisions could be viewed either as instances of what has emerged as Article 19(c) VCLT or, conceivably, as serving to define prohibited reservations in accordance with Article 19(a) VCLT (in which case, as with all prohibited reservations, there would be no 'need' for other States and international organizations to react 'for they have already expressed their objection to it in the treaty itself). ${ }^{91}$

The Vienna Convention invokes the concept of a treaty's 'object and purpose' on one other occasion in articulating its system on reservations, and this is to restrict the application of Article 19 VCLT in circumstances where it appears from the limited number of the negotiating States and the object and purpose of a treaty that the application of the treaty in its entirety between all the parties is an essential condition of the consent of each one to be bound by the treaty'; here, 'a reservation requires acceptance by all the parties'. ${ }^{92}$ This reference to so-called 'plurilateral treaties $^{93}$ or 'restricted multilateral treaties ${ }^{94}$ is further evidence of the

901249 UNTS 13 ("[a] reservation incompatible with the object and purpose of the present Convention shall not be permitted'). Additionally, Art. 29(2) provides that each State Party may 'declare that it does not consider itself bound' by Art. 29(1) of the Convention - relating to the dispute settlement mechanisms of negotiation, arbitration or judicial settlement. It is encouraging to note that, in terms of more recent practice, objections to reservations assume more of an explanatory character regarding compatibility with the Convention's 'object and purpose': J. Connors, 'Article 28' in M. A. Freeman, C. Chinkin and B. Rudolf (eds.), The UN Convention on the Elimination of All Forms of Discrimination against Women (Oxford: Oxford University Press, 2012), pp. 565-595, at pp. 576-577.

91 Waldock, First Report on the Law of Treaties, supra n. 23, at p. 65.

92 Art. 20(2) VCLT: supra n. 1 (emphasis added). This is why Pellet argues that Art. 19(c) VCLT 'displays a subsidiary character', i.e. 'only because it intervenes outside the hypotheses envisaged by paragraphs 2 and 3 of Article 20 of the Convention': supra n. 21, at p. 443. For Müller, Arts. 20(2) and 20(3) VCLT 'are nothing more than "savings clauses", which 'exclude the applicability of the "flexible" regime to certain categories of treaties without specifying the applicable rules': D. Müller, 'Article 20 (1969)' in Corten and Klein (eds.), supra n. 21, pp. 489-537, at p. 519.

93 See Aust, supra n. 20, at p. 125 (treaties 'negotiated between a limited number of States with a particular interest in the subject matter') and C. Walter, 'Article 20' in Dörr and Schmalenbach (eds.), supra n. 6, pp. 287-306, at p. 296.

94 Sinclair, supra n. 11, at p. 33. Sinclair gives as 'obvious examples' the Treaty establishing the European Economic Community and the other basic European Community treaties: ibid., at p. 34. Aust's example is that of the 1959 Antarctica Treaty, 402 UNTS 71: supra n. 20, at p. 125. Consider, too, the example of the North American Free Trade Agreement, 1867 UNTS 14: J. Brunnée, 'Treaty Amendments' in Hollis (ed.), supra n. 24, pp. 347-366, at p. 350. See, further, Walter, supra n. 93, at p. 298 ('treaties between riparian States relating to the development of a river basin or treaties relating to the building of a hydroelectric dam, scientific installations, etc') and, also, Azaria, supra n. 6, at pp. 103-104. 
typologisation of treaties that occurs at various points within the Vienna Convention. ${ }^{95}$ Plurilateral or restricted multilateral treaties as framed in Article 20(2) VCLT transcend the materiae of a given treaty by concentrating on its 'limited' circle of 'negotiating States'; ${ }^{96}$ it was only in order to bring greater definition to this principle - which, one hastens to contend, is more likely to rest on the intention of the parties than on the conjuring of an abstract numeric ${ }^{97}$ - that reference was made to 'the object and purpose of a treaty' as well as to 'the application of the treaty in its entirety between all the parties [as] an essential condition of the consent of each one to be bound by the treaty'. ${ }^{98}$ In this instance, the reservation will not be governed by the 'incongruent' model of 'bilateral treaty relations' that depends upon State objections to or acceptances of a reservation: ${ }^{99}$ instead, that reservation will require 'acceptance by all the parties', ${ }^{100}$ since ' $\mathrm{t}$ ] he central purpose of [Article 20(2) VCLT] must be seen in the desire to maintain the unanimity rule for treaties where such a patchwork of different bilateral relations is unacceptable in view of their object and purpose. ${ }^{101}$

\section{$* * *$}

Over time, however, this general regime came to be viewed as operating 'unsatisfactorily' for human rights treaties, which, Rosalyn Higgins wrote at the end of the Cold War, 'are not just an exchange of obligations between [S]tates where they can agree at will, in a web of bilateral obligations within a multilateral treaty, what bargains they find acceptable. Human rights treaties ... reflect rights inherent in human beings, not dependent upon grant by the $[\mathrm{S}]$ tate'. ${ }^{102}$ Of course, we are on familiar

95 On this issue, see the contribution to this volume of Brölmann at pp. 79-102 (Chapter 4), and, further, A. V. Lowe, 'The Law of Treaties; Or, Should This Book Exist?' in C. J. Tams, A. Tzanakopoulos and A. Zimmermann (eds.), Research Handbook on the Law of Treaties (Cheltenham: Edward Elgar, 2014), pp. 3-15, at p. 12 (on 'categories of treaty for special treatment').

96 Assuming these are separate considerations: see, further, B. H. Hoekman and P. C. Mavroidis, "WTO "à la carte" or "menu du jour"? Assessing the Case for More Plurilateral Agreements', EJIL, 26 (2015), 319-343.

97 See H. Waldock, Fourth Report on the Law of Treaties, Doc. A/CN.4/177 and Add.1 and 2 (19 March, 25 March and 17 June 1965), p. 51. Indeed, the International Law Commission discussed this in terms of 'treaties drawn up between very few States': YbILC (1965-II), 25. This, Walter maintains, 'can hardly be turned into a concrete figure': supra n. 93, at p. 296.

98 Walter, supra n. 93, at p. 296. ${ }^{99}$ Ibid., at p. 297.

100 As per Art. 20(2) VCLT: supra n. 1. ${ }^{101}$ Walter, supra n. 93, at p. 297.

102 R. Higgins, 'Human Rights: Some Questions of Integrity', Modern L. Rev., 52 (1989), $1-21$, at 11 (claiming that the 'principles' formulated for reservations 'did not of course 
ground with this rhetoric of exceptionalism given the lauding of the 'special characteristics' of the Genocide Convention in Reservations to the Convention on the Prevention and Punishment of the Crime of Genocide, ${ }^{103}$ and, in November 1994, the Human Rights Committee of the 1966 International Covenant on Civil and Political Rights (ICCPR) ${ }^{104}$ issued General Comment No. 24(52), in which it actually sought to embellish the meaning of 'the object and purpose test' (as it called it) ${ }^{105}$ of the Vienna Convention as applied to the ICCPR: ${ }^{106}$

In an instrument which articulates very many civil and political rights, each of the many articles, and indeed their interplay, secures the objectives of the Covenant. The object and purpose of the Covenant is to create legally binding standards for human rights by defining certain civil and political rights and placing them in a framework of obligations which are legally binding for those States which ratify; and to provide an efficacious supervisory machinery for the obligations undertaken. ${ }^{107}$

have in mind at all treaties with their own built-in substantial limitations to the obligations undertaken' (ibid., at 14) and remaining unconvinced that the Covenant's object and purpose 'can be the exclusive touchstone - for while I am ready to concede that purported reservations to non-derogable articles are contrary to the object and purpose of the treaty, it seems to me that so also can be certain reservations to articles [of the Covenant] that are in principle derogable' (ibid., at 15)).

103 And of the 'special character of a human rights' treaty in Human Rights Committee, General Comment No. 24(52): General Comment on Issues Relating to Reservations Made upon Ratification or Accession to the Covenant or the Optional Protocol Thereto, or in Relation to Declarations under Art. 41 of the Covenant, U.N. Doc. CCPR/C/21/Rev.1/Add.6 (1994) (paragraph 18); '[a]lthough treaties that are mere exchanges of obligations between States allow them to reserve inter se application of rules of general international law, it is otherwise in human rights treaties, which are for the benefit of persons within their jurisdiction' (paragraph 8). See, also, Swaine's emphasis of 'the original human rights context in which [these] principles were forged': supra n. 53, at p. 278 (and at pp. 282-283 ('the characteristics of fundamental human rights conventions' like the Genocide Convention)). And Pellet: supra n. 21, at pp. 418 and 421. A. W. B. Simpson is of another view: 'Britain and the Genocide Convention', BYbIL, 73 (2002), 5-64, at 5 ('[t]he [Genocide] Convention belongs to international penal law, not to the international law of human rights').

104999 UNTS 171.

105 General Comment No. 24(52), supra n. 103 (paragraphs 6, 9, 10 and 17).

106 And its First Optional Protocol, 999 UNTS 302 (ibid. (paragraphs 5, 13 and 14)); Second Optional Protocol, 1642 UNTS 414 (ibid. (paragraphs 5 and 15)) and declarations under Art. 41 ICCPR (ibid. (paragraph 17)). See, further, E. A. Baylis, 'General Comment 24: Confronting the Problem of Reservations to Human Rights Treaties', Berkeley JIL, 17 (1999), 277-329.

107 Ibid. (paragraph 7). They may not alone in this regard: see T. Meron, 'The Humanization of Humanitarian Law', AJIL, 94 (2000), 239-278, at 247-253, and, also, L. Brilmayer, 'From "Contract" to "Pledge": The Structure of International Human Rights Agreements', BYbIL, 77 (2006), 163-202. 
As will be appreciated from this motif, and as is apparent from the tenor of General Comment No. 24(52) as a whole, this is an expansive and firmly articulated rendering of the ICCPR's 'object and purpose' so as to encompass (or so the Committee reasoned) reservations:

- 'that offend peremptory norms [of general international law]'; ${ }^{108}$

- to 'provisions in the Covenant that represent customary international law'; ${ }^{109}$

- to Article 1 ICCPR ('denying peoples the right to determine their own political status and to pursue their economic, social and cultural development'); ${ }^{110}$

- to Article 2(1) ICCPR ('the obligation to respect and ensure rights, and to do so on a non-discriminatory basis') ${ }^{111}$ and

- to Article 2(2) ICCPR ('[n]or may a State reserve an entitlement not to take necessary steps at the domestic level to give effect to the rights of the Covenant'). ${ }^{112}$

${ }^{108}$ General Comment No. 24(52), supra n. 103 (paragraph 8).

109 Ibid. It is in this context that the Committee mentioned that a State may not reserve the right to engage in slavery (Art. 8 ICCPR); to torture, to subject persons to cruel, inhuman or degrading treatment or punishment (Art. 7 ICCPR); to arbitrarily deprive persons of their lives (Art. 6(1) ICCPR); to arbitrarily arrest and detain persons (Art. 9 ICCPR); to deny freedom of thought, conscience and religion (Art. 18 ICCPR); to presume a person guilty unless he proves his innocence (Art. 15 ICCPR); to execute pregnant women or children (Art. 6(5) ICCPR); to permit the advocacy of national, racial or religious hatred (Art. 20(2) ICCPR); to deny persons of marriageable age the right to marry (Art. 23 ICCPR) or to deny to minorities the right to enjoy their own culture, profess their own religion, or use their own language (Art. 27 ICCPR): ibid.

110 Ibid. (paragraph 9). ${ }^{111}$ Ibid.

112 Ibid. This should not be taken to suggest, however, that the ICCPR's object and purpose precludes reservations to all protections: the Committee was of the view that 'while reservations to particular clauses of Article 14 [ICCPR] may be acceptable, a general reservation to the right to a fair trial would not be': ibid. Why this should be so is not immediately clear since all seven subparagraphs of Art. 14 ICCPR - '[a]ll persons shall be equal' (Art. 14(1)); '[e]veryone charged' (Art. 14(2)); 'everyone shall be entitled' (Art. 14(3)); ' $[\mathrm{i}] \mathrm{n}$ the case of juvenile persons' (Art. 14(4)); '[e]veryone convicted of a crime' (Art. 14(5)); 'the person who has suffered punishment' (Art. 14(6)) and '[n]o one shall be liable' (Art. 14(7)) - fit the Committee's mould of 'benefit[s] of persons within their jurisdiction' (paragraph 8). See, also, the Committee's statement that ' $[w]$ hile there is no automatic correlation between reservations to non-derogable provisions, and reservations which offend against the object and purpose of the Covenant, a State has a heavy onus to justify such a reservation' (paragraph 10). 
Furthermore, the Committee concluded that ' $[t]$ he Covenant consists not just of specified rights, but of important supportive guarantees':

These guarantees provide the necessary framework for securing the rights in the Covenant and are thus essential to its object and purpose. Some operate at the national level and some at the international level. Reservations designed to remove these guarantees are thus not acceptable. Thus, a State could not make a reservation to [Article 2(3)] of the Covenant, indicating that it intends to provide no remedies for human rights violations. Guarantees such as these are an integral part of the structure of the Covenant and underpin its efficacy. The Covenant also envisages, for the better attainment of its stated objectives, a monitoring role for the Committee. Reservations that purport to evade that essential element in the design of the Covenant, which is also directed to securing the enjoyment of the rights, are also incompatible with its object and purpose. A State may not reserve the right not to present a report and have it considered by the Committee. The Committee's role under the Covenant, whether under [A]rticle 40 or under the Optional Protocols, necessarily entails interpreting the provisions of the Covenant and the development of a jurisprudence. Accordingly, a reservation that rejects the Committee's competence to interpret the requirements of any provisions of the Covenant would also be contrary to the object and purpose of that treaty. ${ }^{113}$

The Committee thus did not hold back on the 'attendant requirements' for rights under the ICCPR to be 'ensured to all those under a State's jurisdiction', ${ }^{114}$ and, following on from this, it stridently concluded that '[i]t necessarily falls to the Committee to determine whether a specific reservation is compatible with the object and purpose of the [ICCPR]: ${ }^{115}$ 'necessarily' because, the Committee thought in part, 'it is an inappropriate task for States parties in relation to human rights treaties' to undertake. $^{116}$ This, then, in the Committee's view, had become a struggle for the soul - that is, a struggle for realising the object and purpose - of the ICCPR, jeopardised not so much by the vagaries of the concept but by the somewhat erratic practices of States in response to reservations to the ICCPR. Objections to these reservations have been 'occasional', the Committee said, brought on by the fact that States 'have not seen any legal interest in or need to object to reservations'. ${ }^{117}$ For the

\footnotetext{
113 Ibid. (paragraph 11). ${ }^{114}$ Ibid. (paragraph 12). ${ }^{115}$ Ibid. (paragraph 18).

$116 \mathrm{Ibid}$. (and 'in part because it is a task that the Committee cannot avoid in the performance of its functions'). At paragraph 17: the VCLT provisions 'on the role of State objections in relation to reservations are inappropriate to address the problem of reservations to human rights treaties'.

117 Ibid. (paragraph 17). Said the Committee:
} 
Committee, this struggle could not be resolved without engaging the question of 'the legal authority to make determinations as to whether specific reservations are compatible with the object and purpose of the [ICCPR]'. ${ }^{118}$ The Committee boldly judged itself to be indispensable to that task, an approach that at its heart sought to recapture some of the initial promise of the concept's objectivity by injecting a measure of institutional coherence and discipline into the process while, at the same time, retaining the system of 'reservatory dialogue' encountered as far back as the Reservations advisory opinion. ${ }^{119}$ To a greater or lesser degree, and in the view of the Committee, this dialogue must commence with - and within - the reserving State itself, ${ }^{120}$ but it must also have an endpoint, and the Committee left us in no doubt as to where (or upon whose say-so) it thought that should be.

\title{
$* * *$
}

We have now almost come full cycle because, in the recent jurisprudence of the International Court of Justice, reservations to the Genocide Convention - specifically to the compromissory clause of Article IX of that Convention, ${ }^{121}$ the focal point of many of the reservations that had

\begin{abstract}
The absence of protest by States cannot imply that a reservation is either compatible or incompatible with the object and purpose of the Covenant. Objections have been occasional, made by some States but not others, and on grounds not always specified; when an objection is made, it often does not specify a legal consequence, or sometimes even indicates that the objecting party nonetheless does not regard the Covenant as not in effect as between the parties concerned. In short, the pattern is so unclear that it is not safe to assume that a non-objecting State thinks that a particular reservation is acceptable. In the view of the Committee, because of the special characteristics of the Covenant as a human rights treaty, it is open to question what effect objections have between States inter se.
\end{abstract}

See, further, C. J. Redgwell, 'Reservations to Treaties and Human Rights: Committee General Comment No. 24(52)', ICLQ, 46 (1997), 390-412, at 394-399, 404 and 406.

118 Ibid. (paragraph 16). $\quad{ }_{119}$ Pellet, supra n. 21, at p. 479.

120 Or so thought the Committee: 'States should institute procedures to ensure that each and every proposed reservation is compatible with the object and purpose of the Covenant'. General Comment No. 24(52), supra n. 103 (paragraph 20). For an appreciation of the broader significance of this General Comment, see M. Nowak, U.N. Covenant on Civil and Political Rights: CCPR Commentary (Kehl: N.P. Engel, 2nd rev. ed., 2005), pp. xxxxxxvi.

121 Art. IX provides that '[d]isputes between the Contracting Parties relating to the interpretation, application or fulfilment of the present Convention, including those relating to the responsibility of a State for genocide or for any of the other acts enumerated in [A]rticle III, shall be submitted to the International Court of Justice 
inspired the request for the Reservations advisory opinion all those decades ago - have once again come to occupy the attention of the Court. By way of illustration, let us select the order of interim measures from July 2002 in Case Concerning Armed Activities on the Territory of the Congo (New Application: 2002) as well the (related) judgment on jurisdiction and admissibility given in the same case in February $2006 .{ }^{122}$

Upon initiating proceedings against Rwanda in May 2002, the Democratic Republic of the Congo (DRC) sought to challenge Rwanda's reservation to Article IX of the Genocide Convention ${ }^{123}$ (which was one of several treaties invoked to found the jurisdiction of the Court). ${ }^{124}$ Even though it had not objected to this reservation when Rwanda acceded to the Genocide Convention in April 1975, ${ }^{125}$ the DRC's challenge was based on the ground (inter alia) that the reservation is incompatible with the object and purpose of the Convention in that its effect is to exclude Rwanda from any mechanism for the monitoring and prosecution of genocide, whereas the object and purpose of the Convention are precisely the elimination of impunity for this serious violation of international law. ${ }^{126}$ Rwanda, for its part, contended that there was no such incompatibility as its reservation related not to 'the substantive obligations of the parties to the Convention but to a procedural provision', and it cited the statistic that fourteen other States had maintained similar reservations to the Convention (with the majority of the 133 States parties to the Convention raising no objection in this regard). ${ }^{127}$ It is therefore apparent that States may choose, for

at the request of any of the parties to the dispute': supra n. 29. See, further, W. A. Schabas, Genocide in International Law: The Crime of Crimes (Cambridge: Cambridge University Press, 2nd ed., 2009), p. 570.

122 Case Concerning Armed Activities on the Territory of the Congo (New Application: 2002): Democratic Republic of the Congo v. Rwanda (Jurisdiction and Admissibility) (2006) ICJ Rep. 6.

123 The reservation read simply: 'The Rwandese Republic does not consider itself bound by [A]rticle IX of the Convention'. In a communication received on 15 Dec. 2008, Rwanda informed the Secretary-General that it had decided to withdraw this reservation: https://treaties.un.org/Pages/ViewDetails.aspx?src=IND\&mtdsg_no=IV$1 \&$ chapter $=4 \&$ lang $=\mathrm{en} \# 27$.

124 Case Concerning Armed Activities on the Territory of the Congo, supra n. 122, at p. 220 (paragraph 2).

125 As noted by the Court 'as a matter of the law of treaties': ibid., at pp. 32-33 (paragraph 68).

126 Ibid., at p. 30 (paragraph 57).

127 Ibid., at p. 30 (paragraph 61). See, however, the discussion of A. Orakhelashvili, 'Case Concerning Armed Activities on the Territory of the Congo (Democratic Republic of the Congo v. Rwanda), Jurisdiction and Admissibility, Judgment of 3 February 2006', ICLQ, 55 (2006), 753-763, at 759-760. 
essentially strategic reasons, to adopt entirely different formulations of the object and purpose of a treaty, given that concept's role as a crucial determinant of the validity of reservations to its provisions.

For the Court:

Rwanda's reservation to Article IX of the Genocide Convention bears on the jurisdiction of the Court, and does not affect substantive obligations relating to acts of genocide themselves under that Convention. In the circumstances of the present case, the Court cannot conclude that the reservation of Rwanda in question, which is meant to exclude a particular method of settling a dispute relating to the interpretation, application or fulfilment of the Convention, is to be regarded as being incompatible with the object and purpose of the Convention. ${ }^{128}$

By fifteen votes to two, the Court went on to find it had no jurisdiction to entertain the application of the DRC, ${ }^{129}$ but it is the position of five members of this majority - Judges Rosalyn Higgins, Peter Kooijmans, Nabil Elaraby, Hisashi Owada and Bruno Simma - as expressed in a joint separate opinion that is of particular interest to us here. These judges wanted to offer 'a proper reading ${ }^{\text {'130 }}$ of the Court's advisory opinion of May 1951 in order to counter the impression that has formed in recent years of the Court 'stipulating a régime of inter-State laissez-faire in the matter of reservations' - in which 'the object and purpose of a convention should be borne in mind both by those making reservations and those objecting to them, everything in the final analysis is left to the States

128 Ibid., at p. 32 (paragraph 67). In the order of July 2002, the Court had much more tentatively observed that the 'reservation does not bear on the substance of the law, but only on the Court's jurisdiction' - and, importantly, that 'it therefore does not appear contrary to the object and purpose of the Convention': ibid., at p. 246 (paragraph 72); the Court had also indicated that Rwanda's reservation to the 1965 International Convention on the Elimination of All Forms of Racial Discrimination, supra n. 89, 'does not appear incompatible with the object and purpose of that Convention': ibid., at p. 244 (paragraph 67).

129 Ibid., at p. 53 (paragraph 128). Seizing on the terms of Art. I of the Genocide Convention - that ' $[t]$ he Contracting Parties confirm that genocide, whether committed in time of peace or in time of war, is a crime under international law which they undertake to prevent and to punish' - Judge Abdul Koroma was of the view in his dissenting opinion that ' $[t]$ he object and purpose of the Genocide Convention is the prevention and punishment of the crime of genocide, and this encompasses holding a State responsible whenever it is found to be in breach of its obligations under the Convention': ibid., at p. 57 (paragraph 12).

130 Joint Separate Opinion of Judges Higgins, Kooijmans, Elaraby, Owada and Simma, ibid., at p. 65 (paragraph 5). 
themselves. ${ }^{131}$ In an opinion that bears considerable resemblance to General Comment No. 24(52) of the Human Rights Committee, ${ }^{132}$ the judges suggested that, in May 1951, the Court was 'clearly not unaware of the hazards inherent in its answers, in the sense that they would entail a veritable web of diverse reciprocal commitments within the framework of a multilateral convention. ${ }^{\text {,133 }}$ They recalled the 'assumption' underpinning the advisory opinion 'of balancing the freedom to make reservations [with] the scrutiny and objections of other States' and went on to report that this has 'turned out to be unrealized: a mere handful of States do this'. ${ }^{134}$

In reflecting back on the advisory opinion in this way, these five judges demarcated precisely what was said and left unsaid by the Court on that occasion (" $\mathrm{t}]$ o observe this reality is not to attempt to fragment a mythical overreaching law on all questions of reservations'), ${ }^{135}$ but their ambition was to work through the intentions behind the 'assumption' of their predecessors. ${ }^{136}$ Their finding suggests that the framework for making valid reservations as posited in May 1951 had not, in the end, optimised conditions for interactional results between States, ${ }^{137}$ with only the faintest

131 Ibid. (paragraph 4). See, also, p. 69 (paragraph 15).

132 Not surprising given the common denominator of Rosalyn Higgins: see Nowak, supra n. 120, at p. xxx. See, also, Joint Separate Opinion of Judges Higgins, Kooijmans, Elaraby, Owada and Simma, ibid., at p. 69 (paragraph 16).

133 Ibid., at p. 66 (paragraph 9).

134 Ibid., at p. 66 (paragraph 11). See, further, the data provided at ibid. (paragraph 10) (recording that twenty-eight reservations to the Genocide Convention have elicited objections from some eighteen States).

135 Ibid., p. 68 (paragraph 13).

136 Supra n. 134. For consideration of reservations made in the absence of objections, see Legality of Use of Force: Yugoslavia v. Spain (Provisional Measures) (1999) ICJ. Rep. 761, at p. 772 (paragraphs 32-33) and Legality of Use of Force: Yugoslavia v. United States of America (Provisional Measures) (1999) ICJ Rep. 916, at p. 924 (paragraphs 24-25), where the 'said reservation' - i.e. by Spain and the United States to Art. IX of the Genocide Convention - 'had the effect of excluding that Article from the provisions of the Convention in force between the Parties'.

137 Though one may of course deduce this from evidence arising from litigation involving reservations - as the United States had done before the Court in Legality of Use of Force when, as the reserving State, it had 'contended that its reservation to Article IX [of the Genocide Convention] is not contrary to the Convention's object and purpose': supra n. 136, at p. 924 (paragraph 22). The United States was here making explicit what was presumably already implicit - otherwise, why would it have made the reservation if it had believed it was contrary to the object and purpose of the Genocide Convention? See Joint Separate Opinion of Judges Higgins, Kooijmans, Elaraby, Owada and Simma, supra n. 130 , at pp. 69-70 (paragraph 18). 
glimpses of a treaty's 'object and purpose' emerging from that process. This consideration weighed a great deal with these judges, as did the fact that it was the Genocide Convention - of all treaties - that was back in the crosshairs of the Court. 'It must be regarded as a very grave matter', the judges exhorted, 'that a State should be in a position to shield from international judicial scrutiny any claim that might be made against it concerning genocide'. ${ }^{138}$ And this fed through to the final paragraphs of the joint separate opinion which kept the door open a chink on how the Genocide Convention may be interpreted in the future, as it is 'not self-evident that a reservation to Article IX [of the Convention] could not be regarded as incompatible with the object and purpose of the Convention and we believe that this is a matter that the Court should revisit for further consideration'. ${ }^{139}$

\section{The Interim Obligation of Article 18 VCLT}

Towards the end of its Reservations advisory opinion in May 1951, the International Court of Justice distinguished between those States entitled to sign or accede to the Genocide Convention (i.e. those that 'have a right to become parties' to the Convention) and those that had signed the Convention but had not yet ratified it. ${ }^{140}$ It did so in order to deal with the final question put to it by the General Assembly, ${ }^{141}$ finding that the latter position was 'different' because ' $\mathrm{t}$ ] he case of the signatory State' triggered 'the question of the legal effect of signing an international convention'. ${ }^{142}$ The Court shared its thoughts as follows:

It is evident that without ratification, signature does not make the signatory State a party to the Convention; nevertheless, it establishes a provisional status in favour of that State. This status may decrease in value and importance after the Convention enters into force. But, both before and after the entry into force, this status would justify more

138 Joint Separate Opinion of Judges Higgins, Kooijmans, Elaraby, Owada and Simma, supra n. 130, at p. 71 (paragraph 25) (where genocide was described as 'one of the gravest crimes ever known').

139 Ibid., at p. 72 (paragraph 29).

140 Supra n. 27, at pp. 27-28 (where signature 'constitutes a first step to participation in the Convention': ibid., at p. 28).

${ }^{141}$ See supra n. $28 . \quad{ }^{142}$ Supra n. 27, at p. 28. 
favourable treatment being meted out to signatory States in respect of objections than to States which have neither signed nor acceded. As distinct from the latter States, signatory States have taken certain of the steps necessary for the exercise of the right of being a party. Pending ratification, the provisional status created by signature confers upon the signatory a right to formulate as a precautionary measure objections which have themselves a provisional character. These would disappear if the signature were not followed by ratification, or they would become effective on ratification. ${ }^{143}$

This theme of the provisional status of the signatory State resonates with the rules subsequently incorporated within the Vienna Convention because it provides that a State that has signed a treaty or exchanged instruments constituting the treaty subject to ratification, acceptance or approval 'is obliged to refrain from acts which would defeat the object and purpose' until that point in time that it has 'made its intention clear not to become a party to the treaty. ${ }^{144}$ The same obligation obtains for a State that has expressed its consent to be bound by the treaty 'pending the entry into force of [that] treaty. ${ }^{145}$ In Article 18 VCLT, the provenance of the interim obligation is thus defined by two alternative sets of circumstance, ${ }^{146}$ and, much like the Court had done before it, the Convention centres on this idea and develops a keen sense of how the relationship between a State and a treaty evolves at various points along

143 Ibid.

144 Art. 18(a) VCLT: supra n. 1. As per Art. 11 VCLT. Though the obligation is in fact stapled to acts of 'simple' as opposed to 'definitive' signature: Bradley, supra n. 24, at p. 212. See, further, Aust, supra n. 20, at p. 89 (who observes that '[i]f there is no indication, express or implied, of the need for ratification the treaty will be presumed to enter into force on signature').

145 Art. 18(b) VCLT: ibid.

146 A third circumstance featured at an earlier point in the history of the Vienna Convention, for the International Law Commission put its weight behind the obligation when a State 'has agreed to enter into negotiations for the conclusion of the treaty' - and 'while these negotiations are in progress'; this did not make it through to the Vienna Convention, however: YbILC (1966-II), 202. See, further, J. S. Charme, 'The Interim Obligation of Article 18 of the Vienna Convention on the Law of Treaties: Making Sense of an Enigma', Geo. Wash. JIL \& Econ., 25 (1992), 71-114; P. V. McDade, 'The Interim Obligation between Signature and Ratification of a Treaty: Issues Raised by the Recent Actions of Signatories to the Law of the Sea Convention with Respect to the Mining of the Deep Seabed', Netherlands ILR, 32 (1985), 5-47, and J. Klabbers, 'Strange Bedfellows: The "Interim Obligation" and the 1991 Chemical Weapons Convention' in E. P. J. Myjer (ed.), Issues of Armed Control Law and the Chemical Weapons Convention (The Hague: Kluwer Law International, 2001), pp. 11-29. See, however, Bradley, supra n. 24, at p. 213 ('signing obligation' and 'interim signing obligation'); p. 214 ('interim signing obligation') and pp. 214-215 ('signing obligation'). 
that treaty's chronological arc - from the moment of signature or exchange of instruments to the signaling of any changed intention toward a treaty and, in the event of expression of consent to be bound, the entry into force of a treaty 'provided that such entry into force is not unduly delayed'. ${ }^{147}$

It may seem curious that the Vienna Convention conceives of such an obligation in the first place, but evidence - indeed, 'a good deal of material' - was on hand well before the Convention came to pass showing that 'States which have signed a treaty requiring ratification have thereby placed certain limitations upon their freedom of action during the period which precedes its entry into force'. ${ }^{148}$ And part of this evidence can be traced back to at least the nineteenth century when, in discussing the matter of treaties of peace, Arbitrator Lieber reasoned with considerable confidence in Ignacio Torres $v$. the United States that 'it is well understood that a peace is not a complete peace until ratified; that, as a matter of course, the ratifying authority has the power of refusing unless, for that time, it has given up this power beforehand, but there can be no doubt that so soon as peace has been preliminarily signed active hostilities ought to cease, according to the spirit of civilization and consistent with the very idea and object of the whole transaction, which is to stop the war and establish the peace'. ${ }^{149}$ For its part, in commenting on the draft articles for the Vienna Convention, the International Law Commission mentioned that, in Certain German Interests in Polish Upper Silesia, ${ }^{150}$ the Permanent Court of International Justice had accepted that 'a signatory State's misuse of its rights in the interval preceding ratification may amount to a violation of its obligations in respect of the treaty.. ${ }^{15}$

${ }^{147}$ Supra n. 145. Note that the Vienna Convention makes a distinction between the 'contracting State' ('a State which has consented to be bound by the treaty, whether or not the treaty has entered into force') under Art. 2(1)(f) and a 'party' ('a State which has consented to be bound by the treaty and for which the treaty is in force') under Art. 2(1)(g): supra n. 1.

148 McNair, supra n. 39, at p. 199 (hence, ibid., 'it must not be assumed that the signature pending the completion of ratification is devoid of all legal effect'). See, also, O. Dörr, 'Article 18' in Dörr and Schmalenbach (eds.), supra n. 6, pp. 219-235, at pp. 222-224.

149 See J. B. Moore, History and Digest of the International Arbitrations to Which the United States Has Been a Party (Vol. IV) (Washington, DC: Govt. Printing Office, 1898), pp. 3798-3801. Importantly, all of the material collated by McNair, supra n. 39, at pp. 199-203, relates to situations 'pending ratification' (ibid., at p. 200) or in the 'interval' between signature and ratification (ibid., at p. 201).

150 1926 PCIJ, Series A, No. 7, p. 30. ${ }^{151}$ YbILC (1966-II), 202. 
To be clear, then, the intention behind this provision of the Vienna Convention is not to bring forward the formal application of the terms of the treaty before the due date of that treaty's entry into force and still less is it to argue for the provisional or 'interim' application of those terms. ${ }^{152}$ Rather, the organising impetus appears to be the optimisation of the conditions for the entry into force of the treaty: that is, to give it more than a good chance of the life intended for it. ${ }^{153}$ In some measure, too, it does appear as though the principle of good faith is being actualised for the signatory State (as well as the State that has ratified prior to the treaty's entry into force), ${ }^{154}$ which, alongside the principles of free consent and pacta sunt servanda, is 'universally recognized' according to the preamble of the Vienna Convention. ${ }^{155}$ And, for D. P. O'Connell, 'good faith' must mean something more than just 'good form': '[i]t has equitable implications that the law cannot ignore [a]nd clearly [the] signature of a treaty is an act of good faith and not an empty gesture'. ${ }^{156}$ The act of signature is thus responsible for 'bringing into play what may be called certain of the mechanics of treaty-making, ${ }^{157}$ but within the broader scheme of the

152 As is provided for in Art. 25 VCLT: supra n. 1. See, further, the chapter by Quast Mertsch in this volume at pp. 303-334 (Chapter 10).

153 Its focus is on the 'commitment to the entire regime': Bowman, supra n. 20, at 353. For Bradley, the obligation is 'designed to ensure that one of the signatory parties ... does not change the status quo in a way that substantially reduces either its ability to comply with its treaty obligation after ratification or the ability of the other treaty parties to obtain the benefit of the treaty': supra n. 24, at p. 215. See, also, Dörr, supra n. 148, at pp. 219-220 ('protects the negotiated instrument', but also, 'protects the legitimate expectation of the other participants').

154 See the discussion of D. P. O'Connell, International Law (Vol. I) (London: Stevens \& Sons, 1970), p. 222, and S. Rosenne, Developments in the Law of Treaties 1945-1986 (Cambridge: Cambridge University Press, 1989), p. 149. The thinking, too, of Judge Fleischhauer in his assessment of Art. 18 VCLT in his dissenting opinion in GabčíkovoNagymaros Project (Hungary/Slovakia) (1997) ICJ Rep. 7, at p. 206.

155 In addition to this stipulation in the third preambular recital, the Vienna Convention makes several explicit references to good faith - in Art. 26 (pacta sunt servanda), Art. 31 (general rule of interpretation), Art. 46 (provisions of internal law regarding competence to conclude treaties) and Art. 69 (consequences of the invalidity of a treaty): supra n. 1.

156 O'Connell, supra n. 154, at p. 222 (in a section in one of his two chapters on treaties entitled 'the legal nature of an unratified treaty'). For its 'moral' worth: H. Kelsen, Principles of International Law (New York, NY: Holt, Rinehart and Winston, 2nd rev. ed., 1962) (with R. W. Tucker), pp. 466-468. See, also, F. Dopagne, 'Article 28 (1969)' in Corten and Klein (eds.), (Vol. I), supra note 21, pp. 718-728, at p. 723.

157 McNair, supra n. 39, at p. 203 (i.e. 'provisions indicating which States have a right to sign the treaty or to become a party to it by accession, or naming a headquarters Government charged with the receipt of instruments of ratification or accession, or permitting a special method of notifying the completion of an instrument of ratification'). It is in 
Vienna Convention, this obligation does not emerge as an unusual occurrence. Rather, the Convention anticipates, as one supposes it must, 'matters arising necessarily before the entry into force of the treaty' such as the authentication of the text, the establishment of the consent of States to be bound by the treaty, the manner or date of the treaty's entry into force, as well as the specific functions of the depositary - which, the Convention states, 'apply from the time of the adoption of its text'. ${ }^{158}$ Indeed, it could be said that, both apart from but also as a result of its interim obligation, Article 18 VCLT contains an auxiliary obligation which is the subject of infrequent comment, and that is that the signatory State must make its intention 'clear' that it will 'not become a party to the treaty' if that is the course of its choosing. ${ }^{159}$

\section{$* * *$}

As for the obligation at hand - 'to refrain from acts which would defeat the object and purpose of a treaty ${ }^{160}$ - this is evidently cast in negative terms and emphatically so: it is for the relevant State not to act in such a manner that would defeat the object and purpose of a treaty with which it is concerned. The language of 'defeat' in this context is strong to be sure, ${ }^{161}$ especially when compared with alternative possibilities for framing this obligation (viz., '[a] State is obliged to refrain from acts tending to frustrate

this context that McNair understands the Court's position on the final question put to it by the General Assembly: supra n. 28.

158 Art. 24(4) VCLT: supra n. 1. See Rogoff, supra n. 8, at 268 ('with the possible exception of obligations arising from its procedural provisions, a treaty has no obligatory force prior to its entry into force'). On the adoption of the text of a treaty, see Art. 9 VCLT: ibid. See, further, A. Pellet, 'Entry into Force and Amendment of the Statute' in A. Cassese, P. Gaeta and J. R. W. D. Jones (eds.), The Rome Statute of the International Criminal Court: A Commentary (Vol. I) (Oxford: Oxford University Press, 2002), pp. 145-184, at p. 152, where it is suggested that, apart from the obligation in Art. 18 VCLT, signatory States are under 'the duty to examine [the] text [of the Statute] in good faith with an eye to determining their definitive position towards it (without their having the formal obligation to become parties). And if they decide to ratify, they must take the necessary steps to be able to meet their obligations on the date the Statute comes into force in relation to them'.

159 See supra n. 147. And, presumably, constitutes an example of 'other matters arising necessarily before the entry into force of the treaty', on which Art. 24(4) VCLT does not purport to be exhaustive: supra note 1. See, further, Dörr, supra n. 148, at pp. 227-228. Art. 18 VCLT - and generic to both circumstances (a) and (b) mentioned in this provision. A comparator provision might be Art. 72(2) VCLT on the consequences of the suspension of the operation of a treaty: '[d] uring the period of the suspension the parties shall refrain from acts tending to obstruct the resumption of the operation of the treaty': supra n. 1.

161 Bowman, supra n. 20, at 352-353. See, also, Aust, infra n. 165. 
the object of a proposed treaty' $)^{162}$ or set against other formulations appearing elsewhere in the Vienna Convention itself (such as the notion of in/compatibility with a treaty's object and purpose ${ }^{163}$ or with the 'effective execution' of that object and purpose). ${ }^{164}$ That said, the obligation is to some extent tempered by the notion of refraining from acts 'which would defeat the object and purpose of a treaty', ${ }^{165}$ suggesting that it is not the position of the Vienna Convention that a treaty's object and purpose must be defeated as a matter of fact: it is sufficient that an act or course of action would, in the fullness of time, come to have the said effect. $^{166}$ The obligation, therefore, is not restricted to those acts which do defeat the object and purpose of a treaty. This nuance of Article 18 VCLT has perhaps got lost along the way, ${ }^{167}$ but it is one that is echoed to a certain extent in the judgment of the International Court of Justice in Case Concerning Military and Paramilitary Activities in and against Nicaragua in June 1986: at one point in its ruling, the Court spoke of acts 'depriving' the treaty of its object and purpose, ${ }^{168}$ and at another, it spoke of 'the obligation not to defeat the object and purpose of the treaty'. ${ }^{169}$ However, the Court also

162 General Assembly, Official Records, Twenty-First Session, Supp. No. 9, A/6309/Rev.1. See, further, W. Morvay, 'The Obligation of a State Not to Frustrate the Object of a Treaty Prior to Its Entry into Force: Comments on Art. 15 of the ILC's 1966 Draft Articles on the Law of Treaties', ZaöRV, 27 (1967), 451-462, at 453, 456 and 458. Another formulation in circulation at that time: 'one party to a treaty must not, pending ratification, do anything which will hamper any action that may be taken by the other party if and when the treaty enters into force'. See McNair, supra n. 39, at p. 200.

163 Art. 19(c) VCLT (reservations) and Art. 58(1)(b)(ii) VCLT (suspension): supra n. 1.

164 Art. 41(1)(b)(ii) VCLT (modification): supra n. 1. On this 'grammatical comparison', consider Dörr, supra n. 148, at p. 233.

165 On this point, see Aust, supra n. 20, at p. 108 (" $[\mathrm{t}]$ he obligation is only to "refrain" (a weak term) from acts that would "defeat" (a strong term) the object and purpose of the treaty').

166 See, in particular, Morvay, supra n. 162, at p. 458 ('the obligation is violated only by acts which are intended to frustrate the object of a treaty and not also by acts which frustrate it unintentionally'). Consider, too, the emphasis of J. Klabbers, 'How to Defeat a Treaty's Object and Purpose Pending Entry into Force: Toward Manifest Intent', Vanderbilt JTL, 34 (2001), 283-331.

167 As per Dörr, supra n. 148, at p. 233 (“'defeating” the object and purpose'; cf. '[t]he obligation to refrain from acts that might affect a treaty that has been signed but not yet ratified': ibid., at p. 222). A nuance not necessarily captured in the title given to Art. 18 VCLT ('[o]bligation not to defeat the object and purpose of a treaty prior to its entry into force').

Case Concerning Military and Paramilitary Activities in and against Nicaragua: Nicaragua v. United States of America (Merits) (1986) ICJ Rep. 14, at p. 136 (paragraph 271) (the Court speaking of being able 'to entertain a claim alleging conduct depriving the treaty of its object and purpose'). See, also, p. 136 (paragraph 272). Also in this vein, acts 'tending to defeat' the object and purpose of a treaty: ibid., at p. 137 (paragraph 273). Ibid., at p. 138 (paragraph 276). 
made reference to acts that are 'calculated to deprive'170 or 'calculated to defeat' ${ }^{171}$ or 'directed to defeating'172 a treaty's object and purpose, ${ }^{173}$ and these are variations of a theme that seem to reflect more closely the actual terms contained in Article 18 VCLT. They hint, too, at the very real differences that exist in harnessing the proper scope of obligation therein contained, but taken together, they provide increasing indication that the concern might in fact be more than the issue of defeat itself, ${ }^{174}$ embracing, too, the intention (or intentions) behind the relevant acts. ${ }^{175}$

Perhaps the most potent of recent examples to shed some light on this interim obligation has come with the United States and its signature of the 1998 Rome Statute of the International Criminal Court (ICC) on 31 December 2000. ${ }^{176}$ On 6 May 2002, under the Administration of President George W. Bush, the United States announced that it did 'not

170 Ibid., at p. 136 (paragraph 272) ('or to impede [the treaty's] due performance').

171 Ibid., at p. 138 (paragraph 276). ${ }^{172}$ Ibid.

173 We must bear in mind, however, that, whatever echoes there may be of the Art. 18 VCLT obligation, this discussion in the Nicaragua Case occurred in the context of customary international law - and in respect of a bilateral treaty already in force between the litigating States: see infra n. 194 and n. 196 (and accompanying text) - but the Court's discussion does sharpen the focus on the way this provision of the Vienna Convention is actually worded.

174 Where the principle of good faith must loom large: supra n. 154. For Dörr, ' $[\mathrm{t}]$ he interim obligation ... is basically an obligation of good faith': supra n. 148, at p. 220. Consider, too, Art. 9 of the 1935 Draft Convention on the Law of Treaties ('under certain circumstances ... good faith may require that pending the coming into force of the treaty the States shall, for reasonable time after signature, refrain from taking action which would render performance by any party of the obligations stipulated impossible or more difficult'): supra n. 16, at 778 .

175 Hence the references in the jurisprudence to 'calculation' (or derivatives thereof) and on the formulation of Art. 18 VCLT itself: supra n. 144 ('would defeat'). See, further, supra n. 166 (and accompanying text).

1762817 UNTS 90. Note that Norway proposed Draft Art. 113 to the Statute - titled 'Early Activation of Principles and Rules of the Statute' - which provided that '[p]ending the entry into force of the Statute, States that have signed the Statute shall, in accordance with applicable principles of international law, refrain from acts that would defeat the object and purpose of the Statute. To this end, in ensuring the international prosecution and suppression of crimes of international concern, States should pay due regard to the relevant principles and provisions contained in the Statute including the performance of their responsibilities in competent organs of the United Nations, with a view to accelerating the achievement of the shared goal of establishing the Court': Draft Statute for the International Criminal Court, Arts. 108 to 116 - Report of the Preparatory Committee on the Establishment of An International Criminal Court, Part 1, A/CONF.183/2/Add.1 (14 Apr. 1998), p. 166. While this proposal seemed to be of 'very broad scope' when compared with Art. 18 VCLT, it was 'attenuated, to be sure, by the use of the conditional (should), always disputable in a treaty text': Pellet, supra n. 158, at p. 152. 
intend to become a party to the treaty' of the Statute ${ }^{177}$ and that, '[a]ccordingly, the United States has no legal obligations arising from its signature' in December 2000. ${ }^{178}$ This latter statement is quite revealing: the United States had come to the conclusion that an act of 'unsigning' was necessary in order to release it not from any 'obligations' under the Rome Statute as such but, rather, under the general law of treaties given its (ongoing) status as a signatory State (although this technical appreciation is not made explicit in these pronouncements). ${ }^{179}$ And one can certainly understand the concerns of the United States: in the interval between signature and 'unsigning' the Rome Statute, ${ }^{180}$ it had concluded a series of controversial 'bilateral non-surrender agreements' with numerous States who were either mere signatories to the Statute (and, thus, in the same legal position as the United States) or who had gone on to become parties to the Statute (which entered into force on 1 July 2002). ${ }^{181}$ Typically, these agreements provided that '[p]ersons of one Party present in the territory of

177 Subject to ratification under Art. 125(2) of the Statute: 'This Statute is subject to ratification, acceptance or approval by signatory States. Instruments of ratification, acceptance or approval shall be deposited with the Secretary-General of the United Nations'. The intention was announced by way of a letter from John R. Bolton, Under Secretary of State for Arms Control and International Security, to U.N. SecretaryGeneral Kofi Annan: http://2001-2009.state.gov/r/pa/prs/ps/2002/9968.htm.

178 Ibid. ${ }^{179}$ Ibid.

180 See E. T. Swaine, 'Unsigning', Stanford L. Rev., 55 (2003), 2061-2089, and, further, N. A. Lewis, 'U.S. Rejects Global Pact on War-Crimes Tribunal: Bush to "Unsign" Clinton-Era Agreement', Int'l H. Trib., 7 May 2002, 1. Some have contested this language: M. Benzing, 'U.S. Bilateral Non-Surrender Agreements and Article 98 of the Statute of the International Criminal Court: An Exercise in the Law of Treaties', Max Planck Yb. UN Law, 8 (2004), 181-236, at 181. The term of 'unsigning' is not free from difficulty, for once signed, the signature of a treaty remains - and is still there, plain for all to see. What the Vienna Convention actually calls for is for the signatory State 'to ma[k]e its intention clear not to become a party to the treaty', and the effect of this expressed intention would be to neutralise the interim obligation contained in Art. 18: I owe this point to Michael Bowman who has sharpened my thinking on it. Note that the French delegate at the Vienna Conference suggested that 'the most obvious way for a State to make clear its intention not to become a party to the treaty was for it to frustrate the object of the treaty'. See United Nations Conference on the Law of Treaties, First Session, U.N. Doc. A/CONF. 39/11/Add.2 (26 March-24 May 1968), p. 100.

181 The first of which was concluded between the United States and Romania - a party to the Statute - on 1 Aug. 2002. See www.amicc.org/docs/US-Romania.pdf. A helpful tabulation of these agreements is provided by J. Kelley, 'Who Keeps International Commitments and Why? The International Criminal Court and Bilateral Nonsurrender Agreements', Am. Pol. Sci. Rev., 101 (2007), 573-589, at 574. See, also, Coalition for the International Criminal Court, 'Status of U.S. Bilateral Immunity Agreements (BIAs)' as of 11 Dec. 2006 (www.iccnow.org/documents/ CICCFS_BIAstatus_current.pdf). 
the other shall not, absent the expressed consent of the first Party, (a) be surrendered or transferred by any means to the International Criminal Court for any purpose, or (b) be surrendered or transferred by any means to any other entity or third country, for the purpose of surrender to or transfer to the International Criminal Court'.

The lawfulness of this practice was taken up by James Crawford, Philippe Sands and Ralph Wilde in a joint legal opinion they prepared for the Lawyers' Committee for Human Rights and the Medical Foundation for the Care of Victims of Torture. ${ }^{183}$ In their view, the object and purpose of the Statute is to put in place effective arrangements to prevent impunity for the crimes over which the ICC will have jurisdiction', ${ }^{184}$ but they reasoned that this 'general' object and purpose is qualified by the Statute's reference to State and diplomatic immunity (under Article 98(1) of the Statute) and a certain class of agreements (under Article 98(2) of the Statute). ${ }^{185}$ And, with respect to the behaviour of the United States:

The question which arises is this: would the conclusion of a bilateral nonsurrender agreement by a signatory to the ICC Statute prevent that State from performing its obligation to the Court and to other State parties to the ICC Statute? The answer would appear to be yes, both in relation to the category of persons addressed by a bilateral non-surrender agreement and the object and purpose of avoiding impunity. The better view, therefore, is that a signatory should avoid entering into a bilateral non-surrender agreement which may not be compatible with the ICC Statute and its Article $98 .{ }^{186}$

182 See S. D. Murphy, 'Contemporary Practice of the United States Relating to International Law: International Criminal Law', AJIL, 97 (2003), 200 (where 'persons' are defined as 'current or former Government officials, employees (including contractors), or military personnel or other nationals of one Party').

183 Their Joint Opinion in the Matter of the Statute of the International Criminal Court and in the Matter of Bilateral Agreements Sought by the United States under Article 98 (2) of the Statute is available at www.amicc.org/docs/Art98-14une03FINAL.pdf (where they conclude, at p. 21 (paragraph 45), that 'the limitation imposed by Article 98(2) concerns the relationship between the relevant person and the "sending State": the person who is present on the territory of the requested State Party must have a nexus with the 'sending State' which goes beyond mere nationality, and his or her presence must have been occasioned by some positive act of the sending State').

184 Ibid., at p. 12 (paragraph 26). And, at p. 13, 'avoiding impunity' (paragraph 28); at p. 14, '[t]he avoidance of impunity' (paragraph 32); at p. 16, 'guaranteeing subjection to a criminal justice process' (paragraph 34 ) and, also at 16, 'to remove impunity' (paragraph 33). For further discussion of the object and purpose of the Rome Statute, consider the contribution to this volume of Wilmshurst at pp. 621-652 (Chapter 19).

Ibid., at p. 16 (paragraph 33)

186 Ibid., at p. 24 (paragraph 55). Though the authors do admit the 'uncertainty' that surrounds whether this provision of the Vienna Convention 'reflects a rule of customary law and the extent of the obligation': ibid., at pp. 23-24 (paragraph 54). 
This approach bases its analysis upon an admixture of the object and purpose of the Rome Statute together with one of the provisions of the Statute; it contrasts with the position of the Parliamentary Assembly of the Council of Europe who, in September 2002, expressed great concern by the efforts of some [S] tates to undermine the integrity of the ICC treaty ${ }^{187}$ and considered that the exemption agreements in question 'are not admissible under the international law governing treaties... according to which $[S]$ tates must refrain from any action which would not be consistent with the object and the purpose of a treaty. ${ }^{188}$

In a strange but satisfying sense, the interim obligation contained in Article 18 VCLT may have accelerated the act of 'unsigning' by the Bush Administration: it suggests that, in the view of the Administration, as long as the signature from December 2000 remained effective - or remained unaffected by an expressed contrary intention or action ${ }^{189}$ - the United States would be bound by certain obligations as a matter of the general law of treaties (as opposed to the contents of the Rome Statute), and most importantly the interim obligation discussed in this section. However, if there is any truth to this claim, ${ }^{190}$ it would have to be on the basis that the obligation expressed in the Vienna Convention - specifically Article 18(a) VCLT $^{191}$ - is reflective of customary international law, because the United States is only a signatory to the Vienna Convention on the Law of Treaties and has been so since 24 April $1970 .{ }^{192}$ That signatory status is also

187 Resolution 1300, Risks for the Integrity of the Statute of the International Criminal Court (25 Sept. 2002) (https://assembly.coe.int/nw/xml/XRef/Xref-XML2HTML-en.asp ?fileid=17045\&lang=en) (paragraph 9).

188 Ibid. (paragraph 10) (which differs from the obligation as stated in Art. 18 VCLT: supra n. 1).

189 Supra n. 177.

190 A possibility that is presented by L. Boisson de Chazournes, A.-M. La Rosa and M. M. Mbengue, 'Article 18 (1969)' in Corten and Klein (eds.), (Vol. I), supra n. 21, pp. 369-403, at p. 396. See, also, C. A. Bradley, 'U.S. Announces Intent Not to Ratify International Criminal Court Treaty', ASIL Insights (May 2002) (regarding Under Secretary Bolton's 'implicit reference to the object and purpose requirement in Article 18 of the Vienna Convention').

191 The Rome Statute had yet to enter into force; it did so on 1 July 2002.

192 On Art. 18 VCLT as an exercise in codification, see Rogoff, supra note 8, at 284 and 287-288. See, further, Boisson de Chazournes, La Rosa and Mbengue, supra n. 190, at pp. 372-383; Gamble and Frankowska, supra n. 23, at 127-128; Dörr, supra n. 148, at pp. 220-221, and O'Connell, supra n. 154, at p. 205. An instance of the application of Art. 18 VCLT qua treaty obligation arose in Öcalan v. Turkey where the European Court of Human Rights observed, in the context of Turkey's signature of Protocol No. 6 to the European Convention on Human Rights, that its 'non-implementation of the capital sentence is in keeping with Turkey's obligations as a signatory State to this Protocol, in 
significant here, because it raises in turn the unedifying prospect of deciphering what the interim obligation entails in respect of the Vienna Convention on the Law of Treaties itself, ${ }^{193}$ which would necessitate some appreciation of what constitutes the object and purpose of the Vienna Convention!

\section{$* * *$}

It needs to be restated that Article 18 VCLT confines its obligation to the timepoints identified earlier in this chapter - of either the interval between signature and ratification or the period preceding the entry into force of a treaty. What, however, is to become of the object and purpose of a treaty once it enters into force ${ }^{194}$ In Case Concerning Military and Paramilitary Activities in and against Nicaragua, the International Court of Justice concluded as part of its dispositif that by committing certain attacks on Nicaraguan territory in 1983 and 1984 and by declaring a general trade embargo on Nicaragua in May 1985, the United States had 'committed acts calculated to deprive of its object and purpose' the 1956 Treaty of Friendship, Commerce and Navigation that it had reached with Nicaragua. ${ }^{195}$ In so doing, the Court was responding to Nicaragua's claim that, amongst constituting violations of other provisions of international law, the actions of the United States

accordance with Article 18 of the Vienna Convention': App. No. 46211/99, 12 March 2003 (paragraph 185).

193 For fourteen other States apart from the United States: Afghanistan, Bolivia, Cambodia, Côte d'Ivoire, El Salvador, Ethiopia, Ghana, Iran, Kenya, Madagascar, Nepal, Pakistan, Trinidad and Tobago and Zambia. Assuming, of course, the customary status of the obligation given the provision that the Vienna Convention makes on its own nonretroactivity. See Art. 4 VCLT: supra n. 1.

194 A matter that carried some currency with Judge Fleischhauer in Gabčíkovo-Nagymaros Project: 'It follows from there that a State party to a treaty in force is not free to engage in - even on its own territory as Czechoslovakia did as from November 1991 - construction works which are designed to frustrate the treaty's very object, i.e., in the present case the creation and the operation of the Joint Project'. Supra n. 154, at p. 206. An important recent addendum from practice is also worth recounting here: the eighth preambular recitation of the Joint Comprehensive Plan of Action (JCPOA) - agreed between Iran, the five permanent members of the Security Council and Germany as well as the European Union in July 2015 and adopted in Oct. 2015 - provides that ' $[\mathrm{t}$ ] $\mathrm{he}$ E3/ $\mathrm{EU}+3$ and Iran commit to implement this JCPOA in good faith and in a constructive atmosphere, based on mutual respect, and to refrain from any action inconsistent with the letter, spirit and intent of the JCPOA that would undermine its successful implementation'. This passage is reproduced verbatim in the 28th operative paragraph of the JCPOA: www.state.gov/documents/organization/245317.pdf.

195 Nicaragua Case, supra n. 168, at p. 148 (paragraph 292(10)) (by twelve votes to three). See, further, 367 UNTS 3. 
were 'such as to defeat the object and purpose' of this bilateral agreement. ${ }^{196}$

The Court made clear that this claim was 'one not based directly on a specific provision' of the Treaty of Friendship, Commerce and Navigation but one that was related to 'a legal obligation of States to refrain from acts which would impede the due performance of any treaties entered into by them'. ${ }^{197}$ In the words of the Court:

if there is a duty of a State not to impede the due performance of a treaty to which it is a party, that is not a duty imposed by the treaty itself. Nicaragua itself apparently contends that this is a duty arising under customary international law independently of the treaty, that it is implicit in the rule pacta sunt servanda. This claim therefore does not fall under the heading of possible breach by the United States of the provisions of the 1956 Treaty, though it may involve the interpretation or application thereof. ${ }^{198}$

The fact that the Court found that this 'claim' does not 'fall under the heading of a possible breach' of the provisions of a treaty takes us back to the anatomy of a treaty mentioned above and edges us beyond its constituent provisions: it instructs us that a treaty mentioned might well comprise more than the sum of its constituent parts - including something other than its formal stipulations, something more than is visible to the naked eye. Seen in this light, the notion of a treaty's object and purpose acquires renewed vigour for, much like the 'duty' of a State 'not to impede the due performance of a treaty to which it is a party', it is there to sustain the conditions for the viability of the treaty once it has entered into force. ${ }^{199}$ In proceeding down this path, the Court did sound an initial note of scepticism about what this claim would entail:

The argument that the United States has deprived the Treaty of its object and purpose has a scope which is not very clearly defined, but it appears that in Nicaragua's contention the Court could on this ground make a blanket condemnation of the United States for all the activities of which Nicaragua complains on more specific grounds. For Nicaragua, the Treaty is 'without doubt a treaty of friendship which imposes on the Parties the obligation to conduct amicable relations with each other', and ' $\mathrm{w}]$ hatever the exact dimensions of the legal norm of "friendship" there can be no doubt of a United States violation in this case'. In other words, the Court is asked to rule that a State which enters into a treaty of friendship binds itself, for so long as the Treaty is in force, to abstain from any act toward the other party 
which could be classified as an unfriendly act, even if such act is not in itself the breach of an international obligation. ${ }^{200}$

The Court was not disposed however to make any 'blanket condemnation' of the acts of the United States and, instead, in two very important paragraphs of the Nicaragua judgment, it moved to specify those activities that did in its view 'deprive' the Treaty of Friendship, Commerce and Navigation of its object and purpose. ${ }^{201}$ As the Court explained in paragraph 275:

it does consider that there are certain activities of the United States which are such as to undermine the whole spirit of a bilateral agreement directed to sponsoring friendship between the two States parties to it. These are: the direct attacks on ports, oil installations, etc. ... and the mining of Nicaraguan ports ... Any action less calculated to serve the purpose of 'strengthening the bonds of peace and friendship traditionally existing between' the Parties, stated in the Preamble of the Treaty, could hardly be imagined. ${ }^{202}$

And in paragraph 276:

While [certain] acts of economic pressure are less flagrantly in contradiction with the purpose of the Treaty, the Court reaches a similar conclusion in respect of some of them. A State is not bound to continue particular trade relations longer than it sees fit to do so, in the absence of a treaty commitment or other specific legal obligation; but where there exists such a commitment, of the kind implied in a treaty of friendship and commerce, such an abrupt act of termination of commercial intercourse as the general trade embargo ... will normally constitute a violation of the obligation not to defeat the object and purpose of the treaty. The 90 per cent cut in the sugar import quota of 23 September 1983 does not on the other hand seem to the Court to go so far as constitute an act calculated to defeat the object and purpose of the Treaty. The cessation of economic aid, the giving of which is more of a unilateral and voluntary nature, could be regarded as such a violation only in exceptional circumstances.... As to the opposition to the grant of loans from international institutions, the Court cannot regard this as sufficiently linked with the $1956 \ldots$ Treaty to constitute an act directed to defeating its object and purpose. ${ }^{203}$

200 Nicaragua Case, supra n. 168, at pp. 136-137 (paragraph 273).

${ }^{201}$ Ibid., at p. 138 (paragraph 275). ${ }^{202}$ Ibid.

203 Ibid. (paragraph 276). As for the acts of economic pressure discussed at the start of this passage, the Court had itemised these at an earlier point in its judgment: cessation of economic aid (Apr. 1981); action to oppose or block loans to Nicaragua in the Bank for International Reconstruction and Development and the Inter-American Development Bank; modification of the system of quota for United States imports of sugar (Sept. 1983) and the total trade embargo (May 1985), i.e. prohibition of all imports from and exports to Nicaragua, the barring of Nicaraguan vessels from the United States ports and the 
In its judgment, the Court therefore assesses, measure for measure, each of the actions of the United States as against the object and purpose of the Treaty of Friendship, Commerce and Navigation - and, through its reasoning, the Court came to confer a certain tangibility upon the concept of the Treaty's object and purpose as a juridical force over and above those of its twenty-five individual provisions. What is worth remarking, too, is how the Court chose to characterize the ongoing legal significance of a treaty's object and purpose after its entry into force: there is evident in its judgment an unmistakeable mirroring of the contents of Article 18 VCLT for the Court spoke of 'a violation of the obligation not to defeat the object and purpose of the treaty', 204 'an act calculated to defeat the object and purpose of the Treaty ${ }^{205}$ and 'an act directed to defeating its object and purpose'. ${ }^{206}$ Again, 'defeat of a treaty's object and purpose' does not appear to be the ultimate or exclusive question: the Court also directed itself toward the consideration of the calculation - and, presumably, the intention - of the recalcitrant State. This element should not be lost amongst the Court's description of 'acts of economic pressure' that are 'less flagrantly in contradiction with the purpose of the Treaty ${ }^{207}$ or its finding 'that the United States is in breach of a duty not to deprive the [Treaty of Friendship, Commerce and Navigation] of its object and purpose, ${ }^{208}$ for in the dispositif of the judgment, the Court held very clearly that the United States had indeed 'committed acts calculated to deprive of its object and purpose the Treaty of Friendship, Commerce and Navigation' of January $1956 .{ }^{209}$ Such

exclusion of Nicaraguan aircraft from air transportation to and from the United States.

${ }^{204}$ Ibid.

See ibid., at pp. 69-70 (paragraphs 123-125).

205 Ibid. (and 'action less calculated to serve the purpose': supra n. 202). Also, 'an act calculated to deprive [the treaty] of its object and purpose': ibid., at p. 141 (paragraph 280).

206 Supra n. 203.

207 Nicaragua Case, supra n. 168, at p. 138 (paragraph 276); see, also, supra n. 203.

208 Ibid., at p. 140 (paragraph 280) (in addition to 'acts which are in contradiction with the terms of the Treaty'). Or, indeed, of its summation of the 'claim' of Nicaragua - that 'the United States activities have been such as to deprive the [Treaty of Friendship, Commerce and Navigation] of its object and purpose': ibid., at p. 138 (paragraph 275); see, also, ibid., at p. 135 (paragraph 270) as this does not comport fully with what Nicaragua had claimed.

209 Ibid., at p. 148 (paragraph 292(10)). And, in the same sentence as its reference to the flagrant contradiction with the 'purpose' of the Treaty of Friendship, Commerce and Navigation, the Court said that 'such an abrupt act of termination of commercial intercourse as the general trade embargo of ... May 1985 will normally constitute a violation of the obligation not to defeat the object and purpose of the treaty': ibid., at p. 138 (paragraph 276). 
was the commitment 'of the kind implied in a treaty of friendship and commerce' said the Court, ${ }^{210}$ and it would be engaged irrespective of the actual defeat of the object and purpose of Treaty of Friendship, Commerce and Navigation.

The Court's approach did not command the unanimous support of all colleagues: for Judge Shigeru Oda, the weight attached by the Court to the object and purpose of the Treaty of Friendship, Commerce and Navigation meant that it had 'misinterpreted' the concept of a treaty's object and purpose as 'introduced' by the Vienna Convention a 'principle', he maintained, that 'requires compliance with the letter of obligations subscribed to, and not necessarily the avoidance of conduct not expressly precluded by the terms of the given treaty. ${ }^{211}$ In his dissenting opinion, Judge Stephen M. Schwebel regarded the 'narrower creative category' concerning acts 'tending to defeat the object and purpose of [a] [t]treaty' as 'an injudicious extension by the Court of the jurisdiction afforded it under a treaty of this kind, ${ }^{212}$ and, for Judge Robert Jennings, 'the substance of the Court's decision ... causes ... unease': 'Either those acts are breaches of some provision of the Treaty [of Friendship, Commerce and Navigation] or they have nothing to do with the Treaty. The "object and purpose" of a treaty cannot be a concept existing independently of any of its terms.'. ${ }^{213}$ These are strong misgivings, of course, but they were not sufficient in the end to stall the allocation of a role for a treaty's object and purpose by the Court beyond the explicit terms of the Vienna Convention.

\section{Interpretations of a Treaty's Object and Purpose}

The next appearance of a treaty's object and purpose in the Vienna Convention comes with its rules regarding the interpretation of treaties,

${ }^{210}$ Ibid., at p. 138 (paragraph 276). Although, for Judge Oda, the Court attributed this position to Nicaragua - and 'the Judgment does not make it clear whether [the Court] is espousing this point of view'. Ibid., at p. 250 (paragraph 81). See, further, T. D. Gill, Litigation Strategy at the International Court: A Case Study of the Nicaragua v. United States Dispute (Dordrecht: Martinus Nijhoff Publishers, 1989), p. 264.

211 Ibid., at p. 250 (paragraph 81). Cf. Art. 60(3)(a) VCLT: supra n. 1.

212 Ibid., at p. 387 (paragraph 253). Also raised by Judge Oda: ibid., at p. 250 (paragraph 81) ('It may furthermore be asked where the jurisdiction granted by a treaty clause would ever end if it were held to entitle the Court to scrutinize any act remotely describable as inimical to the object and purpose of the treaty in question').

${ }^{213} \mathrm{Ibid}$., at p. 542 . Although he, too, raised the issue of jurisdiction from this perspective: ibid., at p. 540 . 
where it is provided that '[a] treaty shall be interpreted in good faith in accordance with the ordinary meaning to be given to the terms of the treaty in their context and in light of its object and purpose'. ${ }^{214}$ Through to this point of the Convention, it might have been assumed that the treaty's object and purpose would have made itself known in the course of that treaty's text. This is not so, however, and we are greeted instead with silence on the matter of what constitutes the Vienna Convention's own object and purpose. To take another example, the preambular reference in the 1978 Vienna Convention on Succession of States in Respect of Treaties - to 'general multilateral treaties which deal with the codification and progressive development of international law and those the object and purpose of which are of interest to the international community as a whole is of special importance for the strengthening of peace and international cooperation' does very little to illuminate what the object and purpose of that Convention is, notwithstanding the extensive reliance on that concept. ${ }^{215}$ Incontrovertibly, we are confronted with the very real enigma that 'the object and purpose of a treaty [is] to be determined in light of its object and purpose! '16 $^{216}$

In embarking upon this task, it is probably advisable to recall Alain Pellet's observation - in debt to Blaise Pascal - that '[s] uch a process undoubtedly requires more "esprit de finesse" than "esprit de géométrie', like any act of interpretation, for that matter - and this process is certainly one of interpretation'. ${ }^{217}$ Pellet, as Special Rapporteur on Reservations to Treaties within the International Law Commission, was responsible for producing the International Law Commission's 2011

214 Art. 31(1) VCLT: supra n. 1. Also, on plurilingual treaties, '[e]xcept where a particular text prevails in accordance with [Art. 33(1)], when a comparison of the authentic texts discloses a difference of meaning which the application of articles 31 and 32 does not remove, the meaning which best reconciles the texts, having regard to the object and purpose of the treaty, shall be adopted': Art. 33(4) VCLT (emphasis added): supra n. 1.

2151946 UNTS 3 (fifth preambular recital); the 1978 Vienna Convention is a research marvel for present purposes because it contains eighteen - eighteen! - other references to the concept of a treaty's object and purpose - Arts. 15(b), 17(2), 17(3), 18(3), 18(4), 19(3), 19(4), 20(2)(a), 20(3)(a), 31(1)(b), 31(3), 32(6), 33(2), 33(5), 34(2)(b), 35(c), 36(3) and $37(2)$ - but nowhere does it identify its own object and purpose!

216 W. A. Schabas, 'Reservations to Human Rights Treaties: Time for Innovation and Reform', Canadian YbIL, 32 (1994), 39-81, at 48. Though it is also true that the challenge of interpretation afflicts reservations made elsewhere under Art. 19 VCLT: Pellet, supra n. 21, at pp. 437 and 451 ('[u]ltimately, this is a problem of interpretation: the "general rule of interpretation" expressed in [Art. 31 VCLT] is applicable mutatis mutandis to the examination of the object and purpose of the treaty').

217 See Report of the International Law Commission, Sixty-third Session (26 Apr.-3 June and 4 July-12 Aug. 2011), U.N. Doc. A/66/10/Add.1, pp. 359-360. 
Guide to Practice on Reservations to Treaties, in which it is stated that ' $[\mathrm{t}] \mathrm{he}$ object and purpose of the treaty is to be determined in good faith, taking account of the terms of the treaty in their context, in particular the title and the preamble of the treaty. Recourse may also be had to the preparatory work of the treaty and the circumstances of its conclusion and, where appropriate, the subsequent practice of the parties'. ${ }^{218}$ This is good as far as it goes, seeking to unite various morsels of the treaty anatomy in order to form a coherent proposition that is workable at law, and it suggests that a certain degree of circularity - or, perhaps, symbiosis - is implicated: we are to interpret the terms of the treaty by reference to its object and purpose (Article 31(1) VCLT); we are to interpret the treaty's object and purpose by reference to its terms (Guide to Practice on Reservations to Treaties). ${ }^{219}$

Ian Sinclair, perhaps more helpfully, has sought to structure the act of interpretation so that 'the reference to the object and purpose of the treaty [in Article 31(1) VCLT] is, as it were, a secondary or ancillary process in the application of the general rule of interpretation'. ${ }^{220}$ It becomes a form of delayed reassurance for answers that might emerge from the principal method of ascertaining an 'ordinary meaning' in view of its 'context', although

[i]t may be of course that the intellectual process is so overwhelmingly apparent that it must necessarily and from the very outset exercise a determining influence upon the search for the contextual 'ordinary meaning'; but this is likely to be a rare case, given that most treaties have no single, undiluted object and purpose but a variety of differing and possibly conflicting objects and purposes. ${ }^{221}$

This does seem to reduce the pressure on the function of the concept of a treaty's object and purpose as an immediate tool for exercises of treaty

${ }^{218}$ Guideline 3.1.5.1: ibid.

219 As Pellet has correctly identified in the Commentary to the Guidelines, 'the basic problem is one of interpretation' - and, hence, 'it would appear legitimate, mutatis mutandi, to transpose the principles in [Arts. 31 and 32] of the Vienna Convention ... and to adapt them to the determination of the object and purpose of the treaty': supra n. 217, at p. 361. The Commentary to the Guidelines identifies 'a number of highly disparate elements, taken individually or in combination' from the jurisprudence of the International Court of Justice that have helped it deduce the object and purpose of a treaty: title, preamble, treaty provisions, preparatory work on the treaty and from overall tenor': ibid., at pp. 360-361.

${ }^{220}$ Sinclair, supra n. 11, at p. 130.

221 Ibid. See, also, T. D. Grant, Admission to the United Nations Charter Article 4 and the Rise of Universal Organization (Leiden: Martinus Nijhoff, 2009), p. 130. 
interpretation, but at the same time, it alerts us to the discomforting possibility that the concept might flourish in certain contexts but not, alas, in others (i.e. where there is 'no single, undiluted object and purpose'). Whereas this concept might bring clarity and insight, it might equally generate only conflict and irresolution. For example, what exactly is - what are - the object/s and purpose/s of the 1945 Charter on the United Nations? ${ }^{222}$ And, more specifically, how might these resolve the intractable question of whether the right of self-defence in Article 51 of the Charter is confined to situations where 'an armed attack occurs' or whether the right permits anticipatory self-defence in some shape or form? Is the Charter's object and purpose - at least, in part - not to 'save succeeding generations from the scourge of war' as per its preamble? ${ }^{223}$ What of the fact, also by way of the Charter preamble, 'that armed force shall not be used, save in the common interest'? But why, then, admit any right of self-defence at all? What of the establishment of conditions according to the Charter preamble 'under which justice and respect for the obligations arising from treaties and other sources of international law can be maintained'? Is this to be taken as support for the long-standing customary underpinning for a right of anticipatory self-defence in international law $?^{224}$ And are the purposes of the United Nations - to maintain international peace and security; to develop friendly relations among nations based on respect for the principle of equal rights and self-determination of peoples; to achieve international co-operation in solving international problems of an economic, social, cultural, or humanitarian character; to be a centre for harmonising actions of nations - as enunciated in Article 1 of the Charter to be read as elements of the object and purpose of the Charter? ? $^{25}$

According to Sinclair, we must guard against the 'certain dangers' of considering 'that the search for the object and purpose of a treaty is in reality a search for the common intentions of the parties who drew up the treaty' - one of the interpretations made, it will be recalled, in the Reservations advisory opinion. ${ }^{226}$ Here, he sounds a vital note of caution:

2221 UNTS 16.

223 Ibid. (first preambular recital). See, further, the discussion of T. Ruys, 'Armed Attack' and Article 51 of the UN Charter: Evolutions in Customary Law and Practice (Cambridge: Cambridge University Press, 2010), pp. 59-60.

224 R. Y. Jennings, 'The Caroline and McLeod Cases', AJIL, 32 (1938), 82-99.

225 As argued by O. Dörr, 'Article 31' in Dörr and K. Schmalenbach (eds.), supra n. 6, pp. 521-570, at p. 546.

226 Supra n. 27. 
In the case of general multilateral conventions, a search for the common intentions of the parties can be likened to a search for the pot of gold at the end of a rainbow. Many of the parties will have acceded to the treaty and for that reason alone (because they have not taken part in the original framing of the text) must be assumed to have joined not on the basis of what the original negotiators intended but rather on the basis of what the text actually says and means. In addition, a dispute as to treaty interpretation arises only when two or more parties place differing constructions upon the text; by doing so, they are in reality professing differing intentions in regard to that text and, of necessity, professing to have had differing intentions from the very start. If this is the case, there can be no common intentions of the parties aside or apart from the text they have agreed upon. The text is the expression of the intention of the parties; and it is to that expression of intent that one must first look. ${ }^{227}$

$* * *$

Let us now try to explore some of these ideas through the jurisprudence of the International Court of Justice on these matters. The first example is Case Concerning Oil Platforms when Iran instituted contentious proceedings against the United States in November 1992, claiming inter alia that in adopting a patently hostile and threatening attitude towards the Islamic Republic [of Iran] that culminated in the attack and destruction of the Iranian oil platforms [in October 1987 and April 1988], the United States [had] breached the object and purpose' of the 1955 Treaty of Amity, Economic Relations and Consular Rights that it had agreed with Iran. ${ }^{228}$ However, at the oral hearings stage of this case, Iran stated very clearly that 'its claim is strictly based on three very specific provisions' of the 1955 Treaty of Amity, Economic Relations and Consular Rights - namely Articles I, IV(1) and X(1) - and 'not on the violation of the object and purpose of the Treaty as a whole'. ${ }^{229}$ This would release the Court from the challenge that had befallen it in the Nicaragua Case, ${ }^{230}$ although the contested significance of Article I of the Treaty - which provides that ' $\mathrm{t}$ ] here shall be firm and enduring peace and sincere friendship' between Iran and

227 Sinclair, supra n. 11, at pp. 130-131.

228284 UNTS 3. See Case Concerning Oil Platforms: Islamic Republic of Iran v. United States of America (Preliminary Objection) (1996) ICJ Rep. 803, at pp. 806-807 (paragraph 9(c)) and 808 (paragraph 12), and Case Concerning Oil Platforms: Islamic Republic of Iran v. United States of America (Merits) (2003) ICJ Rep. 161, at p. 170 (paragraph 18(c)) - which included, Iran claimed, Arts. I and X(1) of the 1955 Treaty and international law.

229 Case Concerning Oil Platforms (Preliminary Objection), ibid., at p. 809 (paragraph 13). Hence, the Court did not address this aspect in its dispositif: Case Concerning Oil Platforms (Merits), ibid., at p. 218 (paragraph 125(1)).

230 Supra n. 168. 
the United States - meant that the Court had no option but to consider the treaty's object and purpose in order to interpret the scope and meaning of this particular provision. For Iran, this provision 'does not merely formulate a recommendation or desire ... but imposes actual obligations on the Contracting Parties, obliging them to maintain long-lasting peaceful and friendly relations, ${ }^{231}$ and this would impose upon the Parties 'the minimum requirement ... to conduct themselves with regard to the other in accordance with the principles and rules of general international law in the domain of peaceful and friendly relations'. ${ }^{232}$ For the United States, Article I constituted a mere 'statement of aspiration'. ${ }^{233}$

With the change in the substantive formulation of Iran's claims, we can begin to appreciate that the concept of a treaty's 'object and purpose' might in fact affect the structure of the process of interpretation as advanced by Sinclair, for there are going to be situations - as in the Nicaragua Case and potentially in Case Concerning Oil Platforms - where a treaty's object and purpose is front and centre of the dispute: it is integral to the actual claims being presented to the Court for adjudication. In the event, however, Iran progressively invested its energies in the substantive provisions of the Treaty of Amity, Economic Relations and Consular Rights, and this involved the Court scrutinizing the 'general formulation' of Article I of that Treaty - a provision which, the Court said, 'cannot be interpreted in isolation from the object and purpose of the Treaty in which it is inserted'. 234 Reflecting on the 'object' of the Treaty as understood from its preamble, ${ }^{235}$ the Court undertook a brief assessment of kindred bilateral arrangements such as the 1955 Treaty of Friendship and Good Neighbourliness between the French Republic and the United Kingdom of Libya ${ }^{236}$ and found that

231 Case Concerning Oil Platforms (Preliminary Objection), supra n. 228, at p. 812 (paragraph 25).

232 Ibid., at p. 812 (paragraph 25) (i.e. 'in relation to the rules of general international law thus "incorporated" into the Treaty': ibid., at p. 813 (paragraph 25)).

${ }^{233}$ Ibid., at p. 813 (paragraph 26). ${ }^{234}$ Ibid., at p. 813 (paragraph 27).

235 Namely the 'encouraging [of] mutually beneficial trade and investments and closer economic intercourse generally' as well as the regulation of consular relations between two States: ibid., at p. 813 (paragraph 27). On the importance of preambles for the object and purpose of investment treaties, see R. Dolzer and C. Schreuer, Principles of International Investment Law (Oxford: Oxford University Press, 2nd ed., 2012), p. 29, and, also, C. H. Schreuer, L. Malintoppi, A. Reinisch and A. Sinclair, The ICSID Convention: A Commentary (Oxford: Oxford University Press, 2nd ed., 2009), p. 117.

236 Case Concerning Oil Platforms (Preliminary Objection), supra n. 228, at p. 813 (paragraph 27). This agreement came up for consideration in Case Concerning the Territorial Dispute (Libyan Arab Jamahiriya/Chad) (1994) ICJ Rep. 6, at pp. 25-26 (paragraph 52). 
'the object and purpose of the Treaty of 1955 was not to regulate peaceful and friendly relations between the two States in a general sense':

Article I cannot be interpreted as incorporating into the Treaty all of the provisions of international law concerning such relations. Rather, by incorporating into the body of the Treaty the form of words used in Article I, the two States intended to stress that peace and friendship constituted the precondition for a harmonious development of their commercial, financial and consular relations and that such a development would in turn reinforce that peace and that friendship. It follows that Article I must be regarded as fixing an objective, in the light of which the other Treaty provisions are to be interpreted and applied. ${ }^{237}$

The Court was therefore seeking to interpret the scope and meaning of Article I of the Treaty by reference to the treaty's object and purpose; it felt it could not do so, or not do so accurately, in the absence of this consideration, so it understood its 'interpreter's task' as 'not so much to give effect to the treaty's object and purpose, but rather to give effect to its terms in light of that [object] and purpose. ${ }^{238}$

We can carry this thought forward to our second example, which is set in the context of a multilateral treaty: in Whaling in the Antarctic, Australia called upon the Court to declare that the Japanese Whale Research Program under Special Permit in the Antarctic Phase II (JARPA II) did not come 'within the meaning of Article VIII' of the 1946 International Convention for the Regulation of Whaling (ICRW) (which provides, in part, that 'any Contracting Government may grant to any of its nationals a specific permit authorizing that national to kill, take and treat whales for purposes of scientific research subject to such restrictions as to number and subject to such other conditions as the Contracting Government thinks fit'). ${ }^{239}$ That provision accordingly became the effective fulcrum for and of the whole case: Japan had originally taken the position that special permit whaling of the order envisaged by JARPA fell 'entirely outside the scope' of the 1946 Convention; it was to be regarded as 'freestanding' and 'would have to be read in isolation from the other provisions of the Convention'. ${ }^{240}$ It later acknowledged, however, that Article VIII(1)

237 Case Concerning Oil Platforms (Preliminary Objection), supra n. 228, at p. 814 (paragraph 28). Also, the United States had emphasised that its interpretation 'is called for in the context and on account of the "purely commercial and consular" character of the Treaty': ibid., at p. 813 (paragraph 26).

238 Bowman, supra n. 20, at 318 (emphasis in original).

239364 UNTS 1953, Art. VIII(1). See Whaling in the Antarctic: Australia v. France; New Zealand intervening (2014) ICJ Rep. 226, at pp. 238-239 (paragraph 24).

240 As reported by the Court: ibid., at p. 250 (paragraph 52). 
must be interpreted and applied consistently with the other provisions of the Convention, which would result in its forming an exemption from the duties thereby imposed. ${ }^{241}$ For its part, Australia emphasised reading Article VIII in the context of the Convention as a whole, so that the conservation measures undertaken to realise its objectives must remain relevant for whaling for scientific purposes, which 'cannot have the effect of undermining the effectiveness of the regulatory régime as a whole. ${ }^{242}$ New Zealand (intervening) claimed that Article VIII provided a limited discretion' for Contracting Governments to issue special permits for the purpose of scientific research: it does not, however, 'constitute a blanket exemption for special permit whaling from all aspects of the Convention, ${ }^{243}$

In its judgment, the Court recognised the extent to which both Australia and Japan had sought to invoke the object and purpose of the ICRW to 'buttress' their respective argumentation: the object and purpose of conservation (for Australia); the object and purpose of sustainable exploitation (for Japan). ${ }^{244}$ This was done with a view to engineering the correct - or preferred - interpretation of Article VIII(1) ICRW: as recounted by the Court, for Australia, a restrictive interpretation of the provision was called for 'because it allows the taking of whales, thus providing an exception to the general rules of the Convention which give effect to its object and purpose of conservation'; for Japan, the Convention's commitment to sustainable exploitation meant that this was not the case. ${ }^{245}$

The Court was of the view that Article VIII ICRW forms 'an integral part of the Convention' which has to be interpreted in light of the object and purpose of the Convention and taking into account other provisions of the Convention (including its Schedule). ${ }^{246}$ However, '[t]aking into

241 Ibid. ${ }^{242}$ Again, as reported by the Court: ibid. (paragraph 53).

${ }^{243}$ Ibid. (paragraph 54). ${ }^{244}$ Ibid., at p. 251 (paragraph 57).

245 Ibid., at pp. 251-252 (paragraph 57). As for New Zealand, it, too, argued for 'a restrictive rather than an expansive interpretation of the conditions in which the Contracting Government may issue a Special Permit under Article VIII' in order not to undermine 'the system of collective regulation under the Convention': ibid., at p. 252 (paragraph 57). In its submissions to the Court, New Zealand had claimed that ' $[\mathrm{t}]$ he object and purpose of the Convention was, and is ... to replace unregulated, unilateral whaling by States with a system of collective regulation through which the interests of the parties in the proper conservation and management of whales can be achieved': Written Observations of New Zealand (4 Apr. 2013), p. 12 (paragraph 25) (www.icj-cij.org/docket/files/148/ 17386.pdf).

246 Ibid., at p. 251 (paragraph 55). By Art. I of the Convention, the Schedule attached to it 'forms an integral part thereof: supra n. 239. 
account the Preamble and other relevant provisions of the Convention', the Court came to the conclusion that 'neither a restrictive nor an expansive interpretation of Article VIII is justified': 'programmes for purposes of scientific research should foster scientific knowledge; they may pursue an aim other other than either conservation or sustainable exploitation of whale stocks' ${ }^{247}$ Notable in this is the fact that the Court did not itself in this moment explicitly refer to the 'object and purpose' of the Convention. ${ }^{248}$ However, its use of the word 'aim' here does suggest that the 'object and purpose' of the Convention was not far from its mind, and it also connects with the Court's earlier dissection of the Convention's preamble, which in its view indicates that the Convention 'pursues the purposes' of ensuring the conservation of all species of which whales while allowing for their sustainable exploration. Amongst the 'objectives' of the Convention, the Court also said, was the Contracting Parties' decision in the final preambular recital 'to conclude a convention to provide for the proper conservation of whale stocks and thus make possible the orderly development of the whaling industry' with the consequence that '[a]mendments to the Schedule and recommendations by the [International Whaling Committee] may put emphasis on one or other objective pursued by the Convention but cannot alter its object and purpose'. ${ }^{249}$

The conclusion of the Court that Article VIII(1) ICRW did not warrant the interpretation placed on it by either Australia or Japan is indicative of the duality stemming from the object and purpose of the Convention - although the Court did not say this in so many words. This element of duality in the object and purpose of the Convention meant that it could not in the end prove dispositive in the exercise of interpreting the Convention, but even so, there are two crucial points we should not miss in this regard. The first is that the Court disciplined its approach toward the object and purpose of the Convention in that nowhere did it make reference to the 'intention' of the authors of the Convention; the Court's method derived from the contents of the preamble of the Convention; it is this ('object and purpose') read together with 'other

\footnotetext{
247 Ibid., at p. 252 (paragraph 58).

248 The Court does do so towards the end of its judgment when speaking of '[a]ny such interpretation [that] would leave certain undefined categories of whaling activity beyond the scope of the Convention and thus would undermine its object and purpose': ibid., at p. 294 (paragraph 229).

249 Ibid., at p. 251 (paragraph 56).
} 
relevant provisions of the Convention' ('context') that led the Court to conclude that the interpretations of Article VIII(1) ICRW posited before it could not be supported. We thus seem to have a departure, a shift of sorts, from the Reservations advisory opinion with regard to the considerations that are regarded as relevant for a treaty's object and purpose to be construed.

The second point is the premium attached to the Convention's object and purpose in the separate and dissenting opinions attached to the judgment of the Court. These are especially interesting for revealing how some judges perceived the question of the Convention's object and purpose from the perspective of its substance. In the opinion of Judge Hisashi Owada, 'the object and purpose of the Convention is to pursue the goal of achieving the twin purposes of the sustainability of the maximum yield ... of the stocks in question and the viability of the whaling industry. Nowhere in this Convention is to be found the idea of a total permanent ban on the catch of whales'. ${ }^{250}$ Judge Hanqin Xue was of the view that in granting special permits for killing, taking and treating whales for scientific purposes, the Contracting Party must avoid any adverse effect on the stock with a view to maintaining sustainable utilization and conservation of the resources, otherwise the very object and purpose of the Convention would be undermined, a point on which the Parties hold no different views'. ${ }^{251}$ For Judge Julia Sebutinde, '[a Contracting Government] must exercise that discretion [in determining catch limits] consistent with the object and purpose of the ICRW, in that whales may be killed only to the extent necessary for achieving the stated goals of the scientific research programme'), ${ }^{252}$ while others - such as Judge Antônio Augusto Cançado Trindade - advised against any attempt 'to reduce the object and purpose of the ... Convention to the protection or development of the whaling industry' on the grounds that it would be 'at odds with the rationale and structure of the ... Convention as a whole. ${ }^{253}$ And this meant that

250 Ibid., at p. 303 (paragraph 9). Also, '[a]ccording to the structure of the Convention as interpreted in light of its object and purpose, the Contracting Parties expressly recognize the need and the importance of scientific research for the purpose of supporting the "system of international regulation for the whale fisheries to ensure proper and effective conservation and development of whale stocks" ... as established by the Convention': ibid., at p. 311 (paragraph 26).

251 Ibid., at p. 422 (paragraph 7). ${ }^{252}$ Ibid., at p. 434 (paragraph 12).

253 Ibid., at p. 349 (paragraph 3). See, however: ' $[\mathrm{t}$ ] he object and purpose of the Convention point to, as a guiding principle, the conservation and recovery of whale stocks; not to be seen on an equal footing with the sustainable development of the whaling industry or the protection of commercial whaling': ibid., at p. 351 (paragraph 7). In consequence: 
Convention's object and purpose took on more than its materiae or competing materiae to consider the structure of legal relations there intended: Judge Mohamed Bennouna concluded that '[i]n order to strengthen the object and purpose of the Convention, it is clearly desirable that States parties should act within the institutional framework established'. ${ }^{254}$ For Judge Abdulqawi Ahmed Yusuf, 'the Court should have assessed whether the continued conduct of JARPA II ... constitutes an anomaly, which may frustrate the object and purpose of the Convention in light of the amendments introduced to it in recent years which have resulted in an evolution of the regulatory framework of the Convention', ${ }^{255}$ while Judge ad hoc Hilary Charlesworth spoke of 'the overarching object and purpose of the Convention ... which is to create "a system of international regulation" for the conservation and management of whale stocks' [sixth preambular recital]). ${ }^{256} \mathrm{~A}$ treaty's object and purpose can therefore be more than one thing at any given moment in time: as a thing to be interpreted, it exists first and foremost in the eye of the beholder, and Whaling in the Antarctic demonstrates - just as the Reservations advisory opinion had done before it - that this cannot be taken for granted for, like any proposition of law, it is there to be interpreted, argued, contested and adjudicated.

\section{On the Possibilities of Modification and Suspension}

During its lifespan, there may come a point when ' $\mathrm{t}$ ] wo or more of the parties to a multilateral treaty' conclude an agreement for its modification 'as between themselves alone', ${ }^{257}$ a possibility that is anticipated by the Vienna Convention, as is the question of the suspension of a treaty. ${ }^{258}$

'[a] State party - Japan or any other - cannot act unilaterally to decide whether its programme is fulfilling the object and purpose of the ICRW, or the objective of conservation': ibid.

${ }^{254}$ Ibid., at p. $347 .{ }^{255}$ Ibid., at pp. 390-391 (paragraph 26).

256 Ibid., at p. 457 (paragraph 13).

257 Art. 41(1) VCLT: supra n. 1. As opposed to the amendment of a multilateral treaty, which is initiated by a proposal 'as between all the parties' that 'must be notified to all the contracting States', where 'each one of which shall have the right to take part in: (a) [t]he decision as to the action to be taken in regard to such proposal and (b) [t] he negotiation and conclusion of any agreement for the amendment of the treaty': Art. 40(2) VCLT: supra n. 1. See, further, Sinclair, supra n. 11, at pp. 106-107.

258 Art. 42(2) VCLT: supra n. 1 (' $[\mathrm{t}]$ he termination of a treaty, its denunciation or the withdrawal of a party, may take place only as a result of the application of the provisions of the treaty or of the present Convention. The same rule applies to suspension of the operation of a treaty'). 
The suspension of the operation of a treaty can occur in regard to all the parties or to a particular party', ${ }^{259}$ but the Vienna Convention also envisages the suspension 'by agreement [as] between certain parties only, ${ }^{260}$ both of which should be distinguished from the termination of a treaty. ${ }^{261}$ We shall now deal with each of these possibilities in turn, as they provide the next occasions on which the Vienna Convention invokes the concept of a treaty's object and purpose: critically, as a unifying factor for the present analysis, both possibilities examined here relate to treaty action not involving 'all the parties' ${ }^{262}$ to a treaty but to only a select - or, rather, self-selecting - cohort of those parties. ${ }^{263}$

As far as the modification of treaties is concerned, we can appreciate that there are certain parallels to be made with the system for reservations - a reservation, after all, is defined by the Vienna Convention as a unilateral statement made by a State 'whereby it purports to exclude or to modify the legal effect of certain provisions or the treaty in their application to that State 264 - in that the original treaty is presented with a variable geometry of legal relationships as between its parties. ${ }^{265}$ An agreement inter se is reached for modification by limited parties 'to vary provisions of a multilateral treaty in their mutual relations'. ${ }^{266}$

259 Art. 57 VCLT: supra n. 1. And this suspension can occur '(a) [i]n conformity with the provisions of the treaty; or (b) [a]t any time by consent of all the parties after consultation with the other contracting States': ibid.

260 Art. 58 VCLT: supra n. 1.

261 The termination of a treaty may take place '(a) [i]n conformity with the provisions of a treaty; or (b) [a]t any time by consent of all of the parties after consultation with the other contracting States'. See Art. 54 VCLT: supra n. 1. The termination of a treaty can be implied from the conclusion of a later treaty 'if all the parties to it' conclude that later treaty or its provisions 'are so far incompatible with those of the earlier [treaty] that the two treaties are not capable of being applied at the same time'. See Art. 59(1)(a) and (b) VCLT: supra n. 1.

262 Supra n. 257 and n. 259.

263 And, indeed, are brought together in Art. 311(3) of the 1982 United Nations Law of the Sea Convention, 1833 UNTS 3.

264 Art. 2(1)(d) VCLT: supra n. 1 (emphasis added). See, also, Art. 2(1)(d) VCLTSIO: supra n. 80.

265 Note, however, Jonas and Saunders, supra n. 6, at 575 ('a modification, which is concluded between only a fraction of [S]tates party, is presumably less disruptive than a reservation, which the reserving [S]tate makes vis-à-vis all other [S]tates party').

${ }^{266}$ K. Odendahl, 'Article 39' in Dörr and Schmalenbach (eds.), supra n. 6, pp. 699-707, at p. 699. See, also, Sinclair, supra n. 11, at p. 185, and H. Aufricht, 'Supersession of Treaties in International Law', Cornell Law Q., 37 (1952), 655-700, at 671. Though Koskenniemi adroitly observes that ' $[i]$ nter se agreements give rise to two types of legal relations: the "general" relations that apply between all the parties to the original treaty and the 
The same might also be said, however, for a successful proposal to amend a given treaty, since the Vienna Convention is clear that an amending agreement 'does not bind any State already party to the treaty which does not become a party to the amending agreement', ${ }^{267}$ and Sinclair remarks that the 'parallel' of the amending treaty 'with the effects of the reservations system embodied in the [Vienna] Convention is striking. ${ }^{268}$ That is why the International Law Commission approached the prospect of modification with considerable care and caution, and the track record did not allow modification to be presented in the most flattering light:

Clearly, a transaction in which two or a small group of parties set out to modify the treaty between themselves alone without giving the other parties the option of participating in it is on a different footing from an amending agreement drawn up between the parties generally, even if ultimately they do not all ratify it. For an inter se agreement is more likely to have an aim and effect incompatible with the object and purpose of the treaty. History furnishes a number of instances of inter se agreements which substantially changed the régime of the treaty and which overrode the objections of interested States. Nor can there be any doubt that the application, and even the conclusion, of an inter se agreement incompatible with the object and purpose of the treaty may raise a question of State responsibility. ... the main issue is the conditions under which inter se agreements may be regarded as possible. ${ }^{269}$

"special" relations that apply between the States parties to the inter se agreement': Fragmentation Report, supra n. 6, at p. 155 (paragraph 301).

267 Art. 40(4) VCLT: supra n. 1. As it most assuredly could not under Art. 34 VCLT, and Art. 40(4) VCLT goes on to provide that Art. 30(4)(b) VCLT applies in relation to such State: supra n. 1. Hence, Art. 39 VCLT: supra n. 1 ('[a] treaty may be amended by agreement between the parties'). See, also, Odendahl, supra n. 266, at p. 706, and, further, M. E. Villiger, supra n. 6, at p. 533.

${ }^{268}$ Following Paul Reuter: Sinclair, supra n. 11, at p. 106. See, further, P. Reuter, Introduction au droit des traités (Paris: Éditions A. Colin, 1972), p. 132. However, at the Vienna Conference, Max Sorenson (Denmark) did question the analogy between inter se modifications and reservations: this was 'more apparent than real', he maintained, arguing that '[a]t the time of the conclusion of a multilateral treaty, it might be justifiable to exclude the reservations but, as time passed, the need for inter se modifications could well become apparent': United Nations Conference on the Law of Treaties, First Session, supra n. 180, p. 207. See, further, the discussion of late reservations by Swaine, supra n. 53, at p. 289.

269 International Law Commission, Draft Articles on the Law of Treaties with Commentaries, YbILC (1966-II), 235. In terms of the 'provision' alluded to in the (eventual) Art. 41 VCLT (i.e. 'derogation from which is incompatible with the effective execution of the object and purpose of the treaty as a whole'), the International Law Commission gave as an example 'an inter se agreement modifying substantive provisions of a disarmament or neutralization treaty [that] would be incompatible with its 
How and why, then, is a treaty's 'object and purpose' relevant in this context? According to Article 41(1) VCLT, '[t]wo or more parties to a multilateral treaty may conclude an agreement to modify the treaty as between themselves alone if:

a. the possibility of such modification is provided for by the treaty; or

b. the modification in question is not prohibited by the treaty and:

i. does not affect the enjoyment by the other parties of their rights under the treaty or the performance of their obligations;

ii. does not relate to a provision, derogation from which is incompatible with the effective execution of the object and purpose of the treaty as a whole.

Where 'the possibility of such modification is provided for by the treaty' itself, the concept of a treaty's 'object and purpose' goes unmentioned. It does not - at least, not officially - come into play, presumably because the treaty authors will have taken this factor into account in designing the possibilities and arrangements for modification; ${ }^{270}$ in this, there is perhaps some equation to be made with the situation of authorised reservations under Article 19(b) VCLT. ${ }^{271}$ However, it is where 'the modification in question' is not prohibited in the treaty - a silence that

object and purpose and not permissible under the present article': ibid. The International Law Commission would later observe that modification 'involves ... a degree of "derogation" and "setting aside"': Fragmentation Report, supra n. 6, at p. 51 (paragraph 91).

270 By way of example, consider Art. 311(3) UNCLOS: supra n. 264. This provision does mention that treaty's 'object and purpose' for any modification, though it is better viewed as an instance of authorised modification under Art. 41(1)(a) VCLT rather than Art. 41(1)(b) VCLT (but it does place additional demands on those parties seeking modification ('provided further that such agreements shall not affect the application of the basic principles embodied herein and that the provisions of such agreements do not affect the enjoyment by other States Parties of their rights or the performance of their obligations under this Convention')). See, further, J. Harrison, Making the Law of the Sea: A Study in the Development of International Law (Cambridge: Cambridge University Press, 2011), pp. 78-83. As an example of modification, General Assembly Resolution 48/263 (28 July 1994) is especially interesting for present purposes because in adopting the Agreement Relating to the Implementation of Part XI of UNCLOS (third operative paragraph), the General Assembly recognised the need to provide for the provisional application of that Agreement (tenth preambular recital) - and in the sixth operative paragraph of the Resolution, it called upon States, 'which consent to the adoption of the Agreement to refrain from any act which would defeat its object and purpose' - an unmistakable nod to Art. 18 VCLT: D. Anderson, Modern Law of the Sea: Selected Essays (Leiden: Martinus Nijhoff, 2008), p. 353.

271 Supra n. 75. This includes 'contracting out' arrangements: see K. Odendahl, 'Article 41' in Dörr and Schmalenbach (eds.), supra n. 6, pp. 719-730, at p. 719, and, further, Sinclair, supra n. 11, p. 108. 
recalls the rule contained in Article 19(c) $\operatorname{VCLT}^{272}$ - that the Vienna Convention permits modification on the condition that it 'does not affect the enjoyment by the other parties of their rights under the treaty or the performance of their obligations' 273 and that it 'does not relate to a provision, derogation from which is incompatible with the effective execution of the object and purpose of the treaty as a whole. ${ }^{274}$

In permitting modification to occur under these tightly bound circumstances, it is clear that the Vienna Convention is attempting to recognise and protect at least three constituencies of interest. First, by committing the general law to the possibility of modification in principle, the Convention recognises that, for future reference, ' $[t]$ wo or more' - but not all - of the parties to a multilateral treaty may satisfy their desire to modify their treaty relations 'as between themselves', and, so, it is the interest of the modifying States that provides the impetus for this provision. ${ }^{275}$ Second is the interest of those parties to the original treaty not so intent on or involved in modification: under the treaty, rights are there to be enjoyed and obligations are waiting to be performed - and these are the rights and obligations of these 'other parties'. ${ }^{276}$ There is also a third factor to register in this synopsis, however, and that is the interest of the treaty itself - note how, in the concern it expressed on the possibilities of modification, the International Law Commission spoke of 'the régime of the treaty' - presumably, as reflected in or projected by its object and purpose. The treaty has, after all, come into its own existence over and above the interests of either modifying or non-modifying States, and its 'object and purpose' somehow seem wellplaced to mediate between these interests, ${ }^{277}$ especially if inter se agreements

272 Ibid. 273 Art. 41(1)(b)(i) VCLT: supra n. 1.

274 Art. 41(1)(b)(ii) VCLT: ibid. See A. Watts, The International Law Commission 1949-1998 (Vol. II: The Treaties, Part II) (Oxford: Oxford University Press, 1999), p. 716. In which case the procedural obligation of Art. 41(2) VCLT - that 'the parties in question shall notify the other parties of their intention to conclude the agreement and of the modification to the treaty for which it provides' - arises: supra n. 1. Elias regards this latter obligation as a form of 'protection' for these 'other parties' (i.e. those not involved in the modification) - and not unmoored from the principle of good faith: T. O. Elias, The Modern Law of Treaties (Dobbs Ferry, NY/Leiden: Oceana Publications/A.W. Sijthoff, 1974), p. 97. On this point, see, further, Fragmentation Report, supra n. 6, at p. 154 (paragraph 300).

275 Art. 41(1) VCLT: supra n. 1.276 Art. 41(1)(b)(i) VCLT: supra n. 1.

277 Compare the position of McNair that 'as a matter of principle, no State has a legal right to demand the revision of a treaty in the absence of some provision to that effect contained in that treaty or in some other treaty to which it is a party' and that 'treaty revision is a matter of politics and diplomacy and has little, if any, place in this book' (supra n. 39, at p. 534) with that of Koskenniemi that 'Article 41 seeks a compromise between two requirements, that of meeting the needs of a limited number of parties wishing to 
can be responsible for the 'development of the treaty, fully in line with its ethos and its object and purpose'. ${ }^{278}$ The Vienna Convention thereby stands to preserve the inherently integral character' of the treaty in question. ${ }^{279}$

Additionally, it might be said that the potential vagueness of - or inherent within - the concept of a treaty's 'object and purpose' becomes a sudden strength in the sense that, as a moderating device within the life of a treaty, it is permissive and accommodating of the enterprise of modification while not being too prescriptive of the platforms for future action. It therefore does not foreclose unduly and too far in advance the options of those States intent on pursuing this course. And, in a recurring theme of this chapter, it is noticeable how the Vienna Convention relates the 'object and purpose' of a treaty to particular provisions occurring therein (for it is the derogation from individual provisions that must be found to be incompatible with the effective execution of the object and purpose of the treaty as a whole'). ${ }^{280}$ The upshot seems to be that different provisions of the same treaty resonate in different ways - and to

regulate their relations by inter se rules and that of allowing the other parties to continue applying the treaty in its initial form' (supra n. 6, at p. 156 (paragraph 303)). See, also, P. Reuter, 'Solidarité et divisibilité des engagements conventionnels' in Y. Dinstein and M. Tabory (eds.), International Law at a Time of Perplexity: Essays in Honour of Shabtai Rosenne (Dordrecht: Martinus Nijhoff, 1989), pp. 623-634, at p. 628.

278 Fragmentation Report, supra n. 6, at p. 160 (paragraph 310).

279 An observation made by Alan Boyle in respect of consensus/package deal treaties: 'Reflections on the Treaty as Law-Making Instrument' in A. Orakhelashvili and S. Williams (eds.), 40 Years of the Vienna Convention on the Law of Treaties (London: British Institute of International \& Comparative Law, 2010), pp. 1-28, at p. 6.

280 The qualification of the treaty's object and purpose 'as a whole' is in fact unique within the Vienna Convention and could be viewed as a rhetorical reinforcement of the concept of the treaty's object and purpose: see, further, Bowman, supra n. 153; alternatively/ additionally, the formulation 'leaves open the possibility for minor modifications, which would in a way have the character of a simple "adjustment of what exists", detachable from the treaty as a whole, the object and purpose of which would not be compromised by this aggiornamento': A. Rigaux and D. Simon, 'Article 41 (1969)' in Corten and Klein (eds.), (Vol. II), supra n. 21, pp. 986-1008, at p. 1002. See, also, the distinction between 'the overall aim and purpose of the treaty' and '[the] treaty as a whole': McNair, supra n. 39, at pp. 380-381. In contrast, consider Art. 22(b) of the 1935 Draft Convention on the Law of Treaties (" $[\mathrm{t}]$ wo or more of the States parties to a treaty to which other States are parties may make a later treaty which will supersede the earlier treaty in their relations inter se, only if this is not forbidden by the provisions of the earlier treaty and if the later treaty is not so inconsistent with the general purpose of the earlier treaty as to be likely to frustrate that purpose'): supra n. 16 (emphasis added). 
varying extents - with a treaty's object and purpose, whatever that might be. ${ }^{281}$

And this concentration on particular provisions of a treaty must surely bring to mind the question of the character of obligation that had informed some of the other work of the International Law Commission on the law of treaties. For 'in the case of obligations that could not be broken down into bilateral relationships, an inter se agreement might more easily be understood to be object and purpose of the treaty'. ${ }^{282}$ So, in his discussion of the 'fundamental breach' of a treaty opening up the possibilities of its termination or suspension, Special Rapporteur Gerald Fitzmaurice identified: (i) reciprocal obligations - those based 'on contractual reciprocity consisting of a reciprocal interchange between the parties, each giving certain treatment to, and receiving it from, each of the others'; ${ }^{283}$ (ii) absolute or objective obligations - those of 'an absolute rather than a reciprocal character [involving] obligation[s] towards all the world rather than towards particular parties ${ }^{284}$ producing so-called 'integral treaties ${ }^{285}$ and, finally, (iii) interdependent (or 'fully interdependent type') obligations - where 'the participation of all the parties is a condition of the obligatory force of the treaty ${ }^{286}$ and the obligations 'are of such a kind that, by reason of the character of the treaty, their performance by any party is necessarily dependent on an equal and

281 And, in another point I owe to Michael Bowman, there is an interesting question of the application of Art. 41(1)(b)(ii) VCLT that arises where the purported modification relates to several different provisions of a treaty and it is the cumulative effect which threatens the object and purpose of the treaty.

282 Pronto and Wood, supra n. 9.

283 G. G. Fitzmaurice, Second Report on the Law of Treaties, Doc. A/CN.4/107 (15 March 1957), p. 53 (or, at p. 30, 'obligations of the treaty which consist of a mutual and reciprocal interchange of benefits or concessions as between the parties' and, at p. 31, 'any obligations of the treaty which consist in a reciprocal grant or interchange between the parties of rights, benefits, concessions or advantages').

${ }^{284} \mathrm{Ibid}$., at p. 54 (and, at p. 31, obligations 'of a self-existent character, requiring an absolute and integral application and performance under all conditions').

285 Fitzmaurice also labelled these obligations 'self-existent', and they include 'certain standards or working conditions to prohibit certain practices in consequence of the conventions of the International Labour Organization ... or under maritime conventions as regards standards of safety at sea [and] in the Geneva Conventions of 12 August 1949 on prisoners of war and other matters': ibid., at p. 54.

${ }^{286} \mathrm{Ibid}$., at p. 36. And it is in this class that Fitzmaurice positioned disarmament treaties: 'the obligation of each party to disarm, or not to exceed a certain level of armaments, or not to manufacture or possess certain types of weapons, is necessarily dependent on a corresponding performance of the same thing by all the other parties, since it is of the essence of such a treaty that the undertaking of each party is given in return for similar undertaking by the others'. See ibid., at p. 54 . 
corresponding performance by other parties' ${ }^{287}$ That these characterisations did not find their way into Article $41 \mathrm{VCLT}^{288}$ is not to say that they do not remain an invisible hand in guiding the meaning and import of a treaty's object and purpose: indeed, they may well transport us back to some of the reasoning underpinning the Reservations advisory opinion. ${ }^{289}$

\section{$* * *$}

Article 58 of the Vienna Convention deals with the suspension of the operation of a multilateral treaty as between ' $\mathrm{t}$ ]wo or more parties to a multilateral treaty. ${ }^{290}$ As such, it is a variation or an extension of the thinking behind the law for modification of treaties. The operation of provisions of a treaty can be suspended temporarily and as between themselves alone' if provision is made for this in the relevant treaty, ${ }^{291}$ or if the suspension is not prohibited in the treaty and two conditions are met: the suspension must not affect the other parties' enjoyment of their rights or performance of their obligations ${ }^{292}$ and it must not be incompatible with the object and purpose of the treaty'. ${ }^{293}$ The coincidence with the provision on modification in the Vienna Convention - Article 41 should be clear. ${ }^{294}$ At the Vienna Conference on the Law of Treaties, Shabtai Rosenne (Israel) commented that '[i]t was essential to avoid inter se suspension and inter se modification developing into concealed reservations that would evade the provisions of the draft articles on reservations' ${ }^{295}$ However, he thought it was important not to take the 'analogy' too far, for ' $[\mathrm{w}]$ hat might be permissible in the cases envisaged [for modification] was not necessarily and automatically permissible in the cases contemplated [for suspension]. ${ }^{296}$ Additionally, it ought to be emphasised that the Vienna Convention does not make provision for the termination of a treaty inter se, but there is no reason why this should not

287 Ibid., at p. $31 . \quad 288$ Pronto and Wood, supra n. 9.

289 Supra n. 27. It has been said that the advisory opinion 'presents one of the first signs of the distinction between bilateral and collective obligations': J. Pauwelyn, 'A Typology of Multilateral Treaty Obligations: Are WTO Obligations Bilateral or Collective in Nature?', EJIL, 14 (2003), 907-951, at 909.

290 Art. 58(1) VCLT: supra n. 1. ${ }^{291}$ Art. 58(1)(a) VCLT: supra n. 1.

292 Art. 58(1)(b)(i) VCLT: supra n. 1. ${ }^{293}$ Art. 58(1)(b)(ii) VCLT: supra n. 1.

294 M.-P. Lanfranchi, 'Article 58 (1969)' in Corten and Klein (eds.), (Vol. II), supra n. 21, pp. 1311-1324, at p. 1318. See, also, Pauwelyn, supra n. 289, at 914.

295 United Nations Conference on the Law of Treaties, First Session, supra n. 180, p. 349 (paragraph 21).

296 Ibid. (though it is difficult to be more forthcoming on this because of 'scanty' State practice on this matter). 
be permissible in principle - as long as it satisfies those conditions set forth in Articles 41 and 58 VCLT. ${ }^{297}$

A final point does seem to be in order: in addition to their reference to a treaty's 'object and purpose', Articles 41 and 58 VCLT require that the modification or suspension ' $[\mathrm{d}]$ oes not affect the enjoyment by the other parties of their rights under the treaty or the performance of their obligations. ${ }^{298}$ There is a difficulty, here, in that this consideration is presented by the Vienna Convention as separate from that concerning a treaty's 'object and purpose', ${ }^{299}$ when we have observed that a treaty's object and purpose may well incorporate in its remit and reckoning the overall structure of legal relations of that same treaty. Be this as it may, it is telling that this factor has often been explained in the literature by recourse to examples - whether in the form of 'a technical convention in the field of international communications which is essentially of a regulatory character', ${ }^{300}$ and which therefore comports with the model of absolute or objective obligations mentioned earlier, or 'treaties containing reciprocal obligations ... which provide for a mutual exchange of services or the right to specific treatment between all parties, ${ }^{301}$ such as the 1963 Vienna Convention on Consular Relations (VCCR). ${ }^{302}$ This, of course, is a modern paean to the contributions of Special Rapporteur Fitzmaurice, but, rising above the fray of these technicalities, the question to be asked is whether it is appropriate to essentialise the entire contents of treaties in quite this way: plainly, the 1963 Vienna Convention contains 'reciprocal obligations' for those States who are its parties, but is it confined to those 'reciprocal obligations'? ${ }^{303}$ What of the 'individual rights' pronounced in

297 As argued by Sinclair, supra n. 11, at p. 185.

298 Respectively for modification (Art. 41(1)(b)(i) VCLT) and suspension (Art. 58(1)(b)(1)): supra n. 1.

299 Which may prove to be 'unduly onerous in practice' according to Sinclair (regarding modification): supra n. 11, at p. 109.

300 Ibid. ${ }^{301}$ Lanfranchi, supra n. 294, at p. 1317.

302500 UNTS 95 (which 'logically results in a limitation on the possibility of inter se suspension': Lanfranchi, supra n. 294, at p. 1317).

${ }^{303}$ Note, however, the subtle qualification of the International Law Commission in its Fragmentation Report:

There is no doubt about the relevance of the distinction between the two groups [i.e. reciprocal and non-reciprocal] of treaties. The 196[9] Vienna Convention on the Law of Treaties and the 1963 Vienna Convention on Consular Relations are examples of treaties containing essentially reciprocal obligations. The parties may at will derogate from those obligations in their relations inter se. This is not so in regard to a disarmament treaty, for example, where the performance by one party of its obligations is 
Article 36 VCCR? ${ }^{304}$ Do these constitute 'human rights'? ${ }^{305}$ And does this make the VCCR a human rights treaty ${ }^{306}$ Furthermore, how might these questions be answered if we factor into the equation the object and purpose or the objects and purposes - of the VCCR? ${ }^{307}$

\section{The Question of Material Breach}

Finally, to the question of 'material breach' and to Article 60 VCLT which operationalises the principle of inadimplenti non est adimplendum ('a party cannot be held to respect its obligations under a treaty if the other party refuses to honour them, and if both obligations form a synallagma'). ${ }^{308}$ Article 60 VCLT defines the concept of material breach as consisting in 'a repudiation of the treaty not sanctioned by the present Convention ${ }^{309}$ or 'the violation of a provision essential to the accomplishment of the object or purpose of the treaty'. ${ }^{310}$ It proceeds to allocate a series of entitlements and remedies for the event of material breach: other parties may suspend the operation of the treaty in whole or in part or terminate it between themselves and the defaulting State or as between all parties; ${ }^{311}$ a party specially affected by the material breach may suspend the operation of the
a prerequisite for the performance by the other parties of theirs. A breach by one party is in effect a breach vis-à-vis all the other parties. A human rights convention, for its part, is an absolute or 'integral' treaty. The obligations it imposes are independent of any expectation of reciprocity or performance on the part of other parties of their obligations.

Fragmentation Report, supra n. 6, at pp. 160-161 (paragraph 312).

304 As framed by the International Court of Justice: Case Concerning Avena and Other Mexican Nationals: Mexico v. United States of America (2004) ICJ Rep. 12, at p. 35 (paragraph 40). See, further, the contribution to this volume of Hampson at pp. 538-577 (Chapter 17) (and her engagement with Lea Brilmayer, supra n. 107).

305 A point on which the International Court of Justice did not want to commit: ibid., at p. 61 (paragraph 124).

306 According to Pellet, the 'religious war' - or debate - on permissible reservations is in fact 'focused on reservations to normative treaties to the exclusion of those which envisage synallagmatic rights and duties of the parties': Pellet, supra n. 21, at p. 418.

307 As discussed by the Court: supra n. 304, at p. 48 (paragraph 85). The VCCR, notably in its preamble, realises 'that the purpose of such privileges and immunities is not to benefit individuals but to ensure the efficient performance of functions by consular posts on behalf of their respective States': supra n. 302 (fifth preambular recital).

308 B. Simma and C. J. Tams, 'Article 60 (1969)' in Corten and Klein (eds.), (Vol. II), supra n. 21, pp. 1351-1381, at p. 1353 ('an idea of negative reciprocity'). See, also, the contribution to this volume of Tams at pp. 440-467 (Chapter 14).

309 Art. 60(3)(a) VCLT: supra n. 1. ${ }_{310}$ Art. 60(3)(b) VCLT: supra n. 1.

311 Art. 60(2)(a) VCLT: supra n. 1. 
treaty in whole or in part in its relations with the defaulting State ${ }^{312}$ and, finally, any party other than the defaulting State may suspend the treaty in whole or in part with that State if the treaty is of such a character that a material breach of its provisions by one party radically changes the position of every party with respect to the further performance of its obligations under the treaty. ${ }^{313}$

There are two points calling out for immediate attention here. The first relates to the unique disjunction that occurs in Article 60(3) VCLT of a treaty's object 'or' purpose: this is the only time that the Vienna Convention seems to separate out, and present as distinct and alternative propositions, the 'object or purpose' of a treaty - which stands in contrast to all other iterations of the concept of a treaty's object and purpose in the Vienna Convention. Yet, quite remarkably, a good share of the literature tends to skate over or even obscure this fact, ${ }^{314}$ representing Article 60(3) VCLT as if it continues in the same untroubled vein as Articles 18, 19(c), 20(2), 31(3), 33(4), 41(1)(b)(ii) and 58(1)(b)(ii) VCLT. ${ }^{315}$ Given these other references in the Vienna Convention, it is tempting to think that the formulation of a treaty's 'object or purpose' 'appears to have slipped in inadvertently, or [gone] unnoticed'. ${ }^{316}$ However, to the extent that this quirk has been noticed, ${ }^{317}$ there has been no major claim advanced that, with this formulation, the Vienna Convention is somehow attempting to break from the pattern of a concept of a treaty's 'object and purpose' and introduce or posit a rival - and, indeed, lesser - notion of a treaty's 'object or purpose' for determining a 'material breach'. For that is the next step that is available to us. ${ }^{318}$ As one reflects back upon the labours of the Special Rapporteurs on the law of treaties on this question, one can trace the evolution that occurs

\footnotetext{
312 Art. 60(2)(b) VCLT: supra n. $1 . \quad{ }^{313}$ Art. 60(2)(c) VCLT: supra n. 1.

314 As identified supra n. 6.

315 Consider, too, the International Court of Justice: in Legal Consequences for States of the Continued Presence of South Africa in Namibia (South West Africa) Notwithstanding Security Council Resolution 276 (1970), delivered in June 1971, it correctly reproduced Art. 60(3) VCLT in paragraph 94 of its advisory opinion ('object or purpose') but then went on to view General Assembly Resolution 2145 (XXI) 'as the exercise of the right to terminate a relationship in case of a deliberate and persistent violation of obligations which destroys the very object and purpose of that relationship': (1971) ICJ Rep. 16, at p. 47 (paragraph 95).

316 Klabbers, supra n. 6, at 148.

317 See Klabbers, ibid., and, also, Reuter, supra n. 277, at p. 628, and Bowman, supra 20, at 321 .

318 See, for example, Reuter, ibid.
} 
from 'the purposes of a treaty' (Special Rapporteur Fitzmaurice on 'fundamental breach') $)^{319}$ to 'the object and purpose of the treaty' (Special Rapporteur Waldock on 'material breach') ${ }^{320}$ as well as to 'the objects or purposes of the treaty' and 'the object or purpose of the treaty' (International Law Commission on 'material breach'). ${ }^{321}$ What evidence there is suggests that there was a conscious effort on behalf of Special Rapporteur Waldock to systemize the concept of a treaty's 'object and purpose' from the law on reservations to the law on 'material breach', ${ }^{322}$

319 Fitzmaurice, Second Report on the Law of Treaties, supra n. 283, at p. 31. Very helpfully:

The breach must be a fundamental breach of the treaty in an essential respect, going to the root or foundation of the treaty relationship between the parties, and calling in question the continued value or possibility of that relationship in the particular field covered by the treaty ... It must therefore be tantamount to a denial of the treaty obligation, and such as to either $(a)$ destroy the value of the treaty for the other party; $(b)$ justify the conclusion that no further confidence can be placed in the due execution of the treaty by the party committing the breach; or $(c)$ render abortive the purposes of the treaty.

320 H. Waldock, Second Report on the Law of Treaties, Doc. A/CN.4/156 and Add.1-3 (20 March, 10 Apr., 30 Apr. and 5 June 1963), p. 73. Again, very helpfully: 'Provided that, if a material breach of a treaty by one or more parties is of such a kind as to frustrate the object and purpose of the treaty also in the relations between the other parties not involved in the breach, any such other party may, if it thinks fit, withdraw from the treaty'. Indeed, part of Waldock's definition of 'material breach' in this report involved 'the failure to perform which is not compatible with the effective fulfilment of the object and purpose of the treaty': ibid. (emphasis added).

Report of the Work of the International Law Commission on the Work of Its Eighteenth Session, Doc. A/CN.4/189 and Add.1 and 2, YbILC (1966-II), pp. 121 and 253.

322 Waldock, in fact, seemed to be quite specific on the point of a treaty's 'object and purpose' in reflecting on how Special Rapporteur Fitzmaurice 'had seemed perhaps to put the concept of a "fundamental" breach rather high":

The present draft, though inspired by the same general considerations, seeks to define a 'material' breach of a treaty by reference to the attitude adopted by the parties with regard to reservations at the time when they concluded the treaty; and, if they said nothing about reservations at the time, then by reference to the 'object and purpose' of the treaty - the criterion used for determining the power to make reservations in such a case. The reason, of course, is that, although the two questions are not identical, there is a certain connexion between the views of the contracting States concerning the making of reservations and their views concerning what are to be regarded as material breaches of the treaty. It therefore seemed logical, in formulating the present article, to take into account the rules regarding the making of reservations provisionally adopted by the [International Law] Commission ...

Ibid., at 76. All other references in this (i.e. second) report are to a treaty's 'object and purpose': ibid., at 76 (reservations), 77 (material breach), 78 (dissolution of a treaty in 
and the unannounced and unexplained change from 'object and purpose' to 'object or purpose' is best treated as an instance of historical anomaly or, quite possibly, a rare drafting error. ${ }^{323}$

Setting this point or problem aside, our second observation relates to the requirement of Article 60(3)(b) VCLT - that the material breach must relate to a provision of a treaty 'essential to the accomplishment of [its] object or [and] purpose'. In other words, the stipulation is not, 'as could have been expected', to 'the intensity, or gravity, of the breach in question, but requires that the provision breached must have been essential for the accomplishment of the treaty's object and purpose', ${ }^{324}$ further evidence of how the 'object and purpose' is being used to fillet the treaty into its component parts and weight each of them accordingly. ${ }^{325}$ It is worth bearing in mind, though, that, in switching from 'fundamental breach' to 'material breach', Special Rapporteur Waldock made a remark that ought to have an important bearing on how we come to view a treaty's 'object and purpose' when used in this context:

The word 'fundamental' might be understood as meaning that only the violation of a provision directly touching the central purposes of the treaty can ever justify the other party in terminating the treaty. But other provisions considered by a party to be essential to the effective execution of the treaty may have been very material in inducing it to enter into the

consequence of a supervening impossibility or illegality of performance) and 79 (doctrine of rebus sic stantibus). There are no references to 'object or purpose' in this report. See, also, H. Waldock, Fifth Report on the Law of Treaties, Doc. A/CN.4/183 and Add. 1-4 (15 Nov. 1965, 4 Dec. 1965, 20 Dec. 1965, 3 Jan. 1966 and 18 Jan. 1966), p. 36 (where Waldock recalls his earlier invocation of a treaty's 'object and purpose'). See, also, ibid., at pp. 36-37 (material breach).

${ }^{323}$ For this is what was recommended to the conference (in draft Art. 57): A/CONF.39/11 and A/CONF/39/1 I/Add.1, p. 177. In its Draft Articles on the Law of Treaties with Commentaries, the International Law Commission states simply: ' $[t]$ he other and more general form of material breach is that in sub-paragraph $(b)$, and is there defined as a violation of a provision essential to the accomplishment of any object or purpose of the treaty': YbILC (1966-II), 255.

${ }^{324}$ Simma and Tams, supra n. 308, at p. 1359.

${ }^{325}$ Judge Oda reflected on Art. 60(3) VCLT as follows: '[T]here is a degree of such violation justifying termination or suspension, and ... the touchstone of that degree is that the provision violated should be essential to the accomplishment of a treaty's object and purpose. There is no suggestion that the undermining of the object and/or purpose, independently of any breach of a provision, would be tantamount to the violation of the Treaty'. See Nicaragua Case, supra n. 168, at p. 250 (paragraph 80). We should note that Art. 60(3) VCLT sets down a generic definition of 'material breach' - i.e. one that obtains in both bilateral and multilateral treaties as per Arts. 60(1) and 60(2) VCLT: see, further, F. L. Kirgis, Jr., 'Some Lingering Questions about Article 60 of the Vienna Convention on the Law of Treaties', Cornell ILJ, 22 (1989), 549-573, at 553. 
treaty at all, even though these provisions may be of an entirely ancillary character. For example, a clause providing for compulsory arbitration in the event of a dispute as to the interpretation or application of the treaty is purely ancillary to the main purposes of the treaty, but may well be regarded by some parties as an essential condition for agreeing to be bound by the treaty. In that case a refusal to arbitrate would go to the root of the other party's consent to be in treaty relations with the defaulting State. ${ }^{326}$

Let us close this discussion by recalling that Article 60(5) precludes the application of the VCLT rules on - and, thus, qualifies the entitlements and remedies it provides for - material breach to 'provisions relating to the protection of the human person contained in treaties of a humanitarian character, in particular to provisions prohibiting any form of reprisals against persons protected by such treaties'. Its effect, therefore, is to render certain treaty provisions 'sacrosanct'. ${ }^{327}$ At the instigation of Switzerland, an oral proposal was made at the Vienna Conference on the Law of Treaties with the 1949 Geneva Conventions in mind, which 'prohibited reprisals against ... protected persons and were virtually universal, but they were still the subject of some doubts and reservations': 'Such agreements', it was maintained, 'should not be exposed to termination or suspension that would endanger human life'. ${ }^{328}$ The resulting qualification does bring back into sharp relief the importance of the 'special characteristics' of a given convention, ${ }^{329}$ as well as Special

326 Waldock, Second Report on the Law of Treaties, supra n. 320, at p. 75. Cf. Jiménez de Arechaga (Uruguay) who thought at the Vienna Conference on the Law of Treaties that the rule in Art. 60(3) VCLT was 'unduly restrictive' because 'where a treaty contained an arbitration clause, if one party ceased to apply that clause, the other party would be unable to invoke the violation of "a provision essential to the accomplishment of the object and purpose of the treaty"; yet it was a grave breach which ought to come under the rule in [Art. 57]': United Nations Conference on the Law of Treaties, First Session, supra n. 180 , at p. 390.

327 Simma and Tams, supra n. 308, at p. 587 (noting, ibid., that ' $[\mathrm{t}]$ he drafting history suggests that despite the curious wording, this exclusion is intended to cover provisions of international humanitarian law and international human rights law'). See, also, Giegerich, supra n. 6, at p. 1046 (Art. 60(5) VCLT 'immunizes certain treaty provisions against collective or individual termination and suspension in reaction to material breach').

328 United Nations Conference on the Law of Treaties, First Session, supra n. 180, at p. 354. These were not the only agreements in the sights of Switzerland: 'In addition, there were conventions concerning the status of refugees, the prevention of slavery, the prohibition of genocide and the protection of human rights in general; even a material breach of those conventions by a party should not be allowed to injure innocent people'. Ibid.

Supra n. 39. 
Rapporteur Fitzmaurice's explication of 'integral treaties' - or those containing absolute or objective obligations - as

the type of treaty in respect of which a fundamental breach by one party, in addition to giving no right of termination to the other parties, would not even justify a refusal to apply the treaty vis-à-vis the offending party (and where it would perhaps not in any case be practicable to operate such a refusal). Thus, a fundamental breach by one party of a treaty of a treaty on human rights could neither justify termination of the treaty, nor corresponding breaches of the treaty even in respect of nationals of the offending party. The same would apply as regards the obligation of any country to maintain certain standards of working conditions or to prohibit certain practices in consequence of the conventions of the International Labour Organisation; or again under maritime conventions as regards standards of safety at sea. The same principle is now enshrined in express terms in the Geneva Conventions of 12 August 1949 on prisoners of war and other matters [see, in particular, article 2 and other opening articles of each of the four Conventions]. Another type of case is where there exists an international obligation to maintain a certain régime or system in a given area [for example, the régime of the sounds and belts at the entrance to the Baltic Sea. See the Treaty of Copenhagen of 14 March 1857, and the Convention of Washington of 11 April 1857]. ${ }^{330}$

\section{Conclusion}

This chapter has attempted to piece together some of the history and organising logic that has come to inform the concept of a treaty's 'object and purpose', before the Vienna Convention on the Law of Treaties consolidated but also expanded its significance for the modern law of treaties. We have explored the seven - or eight - occasions on which the Vienna Convention has put the concept to work to greater or lesser effect, but it should be said that, on the face of the diplomatic record, the final text of the Vienna Convention might well have understated its appeal as it stood at that point in time. Notwithstanding repeated concerns levelled

330 Fitzmaurice, Second Report on the Law of Treaties, supra n. 283, at p. 54 (emphasis added). In his appraisal, Fitzmaurice juxtaposed 'the character of the treaty' alongside 'the obligation of any party': ibid. See, also, Sinclair, supra n. 11, at p. 190. And we can see Fitzmaurice's idea of 'interdependent' obligations - supra n. 286 - informing Art. $60(2)$ (c) VCLT ('if the treaty is of such a character that a material breach of its provisions by one party radically changes the position of every party with respect to the further performance of its obligations under the treaty'): supra n. 1. 
against its indecipherability, ${ }^{331}$ at the conference leading up to the Vienna Convention, Congo-Brazzaville (the Republic of Congo) proposed the inclusion of a provision to the effect that ' $[\mathrm{a}] \mathrm{n}$ error is a ground of invalidity of a treaty if it relates to the object and purpose of the treaty'. ${ }^{332}$ Similarly, on behalf of twenty-two sponsors representing all regions of the world, Ceylon (Sri Lanka) proposed that '[e]very State has a right to participate in a multilateral treaty which codifies or progressively develops norms of general international law or the object and purpose of which are of interest to the international community'. ${ }^{333}$ States have thus tended to be beholden to the concept as developed by the International Court of Justice in its Reservations advisory opinion: ${ }^{334}$ a proposed amendment at the same conference to replace the words 'object and purpose' with 'character or purpose' in the provision on reservations did not meet with success. ${ }^{335}$ There is also the question of whether a treaty's object and purpose is implicated by the provision on denunciation or withdrawal in Article 56 VCLT where reference is made to 'the nature of the treaty. ${ }^{336}$

That the Vienna Convention - whose signature theme is one of flexibility in the cause of the stable flow of international relations should embrace a concept of such pliability should not come as too much of a surprise. It appears that a treaty's 'object and purpose' affords choice opportunities for the Vienna Convention to pursue and even to achieve this flexibility because the concept does seem to incorporate a deliberative dimension that helps deepen the consciousness of a treaty's integrity. Of course, the Vienna Convention does not engage this concept in an identical manner on each of the seven/eight occasions on which it is invoked: a reservation must not be incompatible with the object and

331 Including at the Vienna Conference on the Law of Treaties: Peru, for instance, observed that 'such vague concepts as "the object and purpose of the treaty" [which] called for ... safeguards for their application': ibid., at p. 436.

332 Ibid., at p. 289.

333 Apparently identical with a proposal forthcoming from Syria: United Nations Conference on the Law of Treaties, Second Session, Vienna, 9 Apr.-22 May 1969 (New York, NY: United Nations, 1970), p. 181.

334 E.g. the United Kingdom: United Nations Conference on the Law of Treaties, Second Session, ibid., at p. 34. See, also, Cameroon, ibid., at p. 30, and Mexico, ibid., at p. 31.

335 Co-sponsored by the United States: United Nations Conference on the Law of Treaties, Second Session, ibid., at p. 35 ('because it had been uncertain whether the traditional reference to the object and purpose of the treaty was intended to cover the concept of the nature and character of the treaty').

336 Art. 56(1)(b) VCLT: supra n. 1 (though this does seem to be a concept with a broader sweep). See, further, ibid. 
purpose of the treaty'; a 'violation' is required of 'a provision essential to the accomplishment of the object or purpose of the treaty' for 'material breach' and the 'interim obligation' requires States 'to refrain from acts which would defeat the object and purpose of a treaty' between signature and ratification or between the period of consent to be bound and entry into force. ${ }^{337}$ And at the same time that the concept of a treaty's 'object and purpose' underscores the integrity of a given treaty, the Vienna Convention intimates that that treaty is divisible into its respective provisions - each of which may well have different relationships with that treaty's object and purpose. ${ }^{338}$

Numerous intricacies have attended our understanding of the concept of a treaty's object and purpose as we move forward from the Vienna Convention. There is a complex portrait that has emerged of the object and purpose - or, better, the objects and purposes - of a treaty's object and purpose as set out in the Vienna Convention. It is true, then, that 'we have a criterion, and a unique, polyvalent criterion; but not a definition of this criterion' in our midst, ${ }^{339}$ and, as argued in this chapter, much stands to be gained from understanding the invocation and relevance of the concept in each of these contexts. In the Nicaragua Case, too, we have seen a life for the object and purpose of a treaty beyond its entry into force, ${ }^{340}$ adding even further hue to that complexity. ${ }^{341}$ Even so, it may be no bad thing that a treaty's object and purpose is there to be interpreted, contested and even, in the course of time, recast, for those possibilities speak not only to the integrity of a given treaty but, also, to the opportunities for its growth and flourishing.

337 And it is not always clear what these differences might/should entail - e.g. between a provision 'derogation from which is incompatible with the effective execution of the object and purpose of the treaty as a whole' (Art. 41(1)(b)(ii) VCLT) and that which is 'essential to the accomplishment' of a treaty's object or purpose (Art. 60(3) VCLT).

338 See, in particular, Arts. 41(1)(ii) and Art. 60(3)(b) VCLT: supra n. 1. See, however, General Comment No. 24(52), supra n. 103, and, also, the position of the International Law Commission: supra n. 50.

339 Pellet, supra n. 21, at p. 447.

340 Supra n. 168. Against the voices of the decriers: supra n. 211 (Judge Oda), n. 212 (Judge Schwebel) and n. 213 (Judge Jennings).

${ }^{341}$ Bowman, supra n. 20, at 353. 